\title{
Pathways to justice for 'atrocity crimes' in Myanmar: is there political will?
}

Article

Accepted Version

Khan, M. Z. I. (2019) Pathways to justice for 'atrocity crimes' in Myanmar: is there political will? Global Responsibility to Protect, 11 (1). pp. 3-41. ISSN 1875-984X doi: https://doi.org/10.1163/1875984X-01101003 Available at https://centaur.reading.ac.uk/77434/

It is advisable to refer to the publisher's version if you intend to cite from the work. See Guidance on citing.

To link to this article DOI: http://dx.doi.org/10.1163/1875984X-01101003

Publisher: Brill

All outputs in CentAUR are protected by Intellectual Property Rights law, including copyright law. Copyright and IPR is retained by the creators or other copyright holders. Terms and conditions for use of this material are defined in the End User Agreement.

\section{www.reading.ac.uk/centaur}

\section{CentAUR}

Central Archive at the University of Reading

Reading's research outputs online 
Pathways to Justice for 'Atrocity Crimes' in Myanmar - is there Political Will? 
'Atrocity Crimes' in Myanmar - is there Political Will?

\section{Pathways to Justice for 'Atrocity Crimes' in Myanmar - is there Political Will? ${ }^{1}$}

\section{Introduction}

As the dust begins to settle ${ }^{2}$, the bone-chilling accounts of the Rohingyas facing 'excessive violence,' 'serious violations of human rights' ${ }^{3}$ and 'ethnic cleansing ${ }^{4}$ calls for ending the culture of impunity and holding the perpetrators accountable. Despite the contested labelling, ${ }^{5}$ Investigating the allegations of atrocity crimes and pursue justice is essential to restore 'international legality and the faith of the world community in the triumph of justice and reason' -- as stressed by the Russian envoy during similar crisis in former Yugoslavia, ${ }^{6}$ and for Myanmar's national reconciliation. But how can we pursue justice for atrocity crimes in the absence of the willingness of the state or United Nations Security Council (UNSC)? What mechanisms and instruments are available and how are those applicable in Myanmar context? The paper seeks to answer these questions exploring the existing scholarship and experiences. First, outlining the definitions of genocide, war crimes, the crime against humanity and ethnic

1, The author, wishes to acknowledge the constructive feedback from Professor Dominik Zaum, University of reading and Professor Ali Riaz, Illinois State University on the initial draft and two anonymous reviews for their insightful comments and suggestions.

2 Myanmar's pledge for taking back the refugees reflects an effort to 'settle the dust.' See Moe Myint, 'Myanmar, Bangladesh to Begin Repatriating Refugees in January', The Irrawaddy, 20 December 2017.

3 As stated by the UN Secretary-General. See S/PV.8060, 28 September 2017, p.2.

${ }^{4}$. Stated by US Secretary of State. See Rex W. Tillerson 'Efforts to Address Burma's Rakhine State Crisis,' Press Statement, 22 November 2017.

${ }^{5}$ Apart from the media reporting, the contesting accounts are available in the statement by the state actors in the UNSC debate. See Thu Thu Aung, 'Govt Information Committee Objects to UN Terminology on Rakhine', The Irrawaddy, 27 September 2017. Poppy McPherson, 'A lot of "fake news": Burmese back Aung San Suu Kyi on Rohingya crises, The Guardian, 20 September 2017. Michael Shafi, 'Myanmar treatment of Rohingya looks like ' textbook ethnic cleansing', says UN' The Guardian, 11 September 2017. Jonathon Head, 'Who is burning down the Burmese Villages?' 11 September 2017, BBC News. Euan McKirdy, Rebecca Wright, and Z. Saeed, 'There is "'genocide going on there" Rohingya huddle on Bangladesh border', CNN, 4 September 2017. Harriet Agerholm, 'Burma soldiers burning bodies of Rohingya Muslims' to conceal evidence', The Independent, 4 September 2017.

${ }^{6}$ The argument is drawn from the statement by the Russian envoy at the UNSC while creating the ICTY. See S/PV.3217, 25 May 1993, p. 44. For a persuasive account of the legacy of impunity in Myanmar see Sally Kantar, The Myanmar Military's Legacy of Impunity How the Rohingya Crisis Fits a Historical Pattern, Foreign Affairs, 14 December 2017. For a historical account of how civilian immunity has operated to shape responses to actual cases see Alex J. Bellamy, Massacres and Morality: Mass Atrocities in an Age of Civilian Immunity, Human Rights Quarterly, 34 (2012) 927-958. 
cleansing (i.e. atrocity crimes) the paper reveals the boundaries for establishing political and individual criminal responsibility as set by the global instruments. Exploring the mandates of the International Crime Tribunals (ICTs) in former Yugoslavia (ICTY), Rwanda (ICTR), Sierra Leone (SCSL), and Cambodia (ECCC), the paper reveals that individual criminal responsibility has been the primary focus for all four ICTs. Second, it examines the ratifications, declaration upon ratifications of relevant instruments and interaction of Myanmar with the UN on a human rights issue to reveal the 'mind' of the state and its potential obligations. Third, exploring the process of establishing the four ICTs, the paper reveals the centrality of political will and outlines three potential pathways for establishing an ICT for the atrocity crimes in Rakhine, Myanmar (ICTM-R). It highlights that international political will has often triumphed and/or shaped the willingness of the host nation to pursue justice. Fourth, analysing the current ideational and material incentives/disincentives to Myanmar the paper outlines its inadequacies to change the status quo and suggests ways to harnessing the willingness of the key actors reflecting their resolve and commitment to justice and reject impunity. Consequently, the paper argues for strong advocacy to reach a consensus mandate to prosecute individuals and not the state, precisely defined jurisdiction, and provisions to integrate host nation's institutional apparatus and judicial wisdom can facilitate establishing the ICTM-R.

\section{Methodology and Scope}

The research is primarily based on content analysis of relevant UN documents; it includes examining the Resolutions, Statements, Reports, and Letters by state actors, UN agencies, Expert Commissions, Civil Society Organisation (CSOs) related to the four ICTs, human rights issues in Myanmar and the declarations upon ratifications of relevant instruments by states. The data, news and commentary on the subject are from official websites, credible media outlets, peer-reviewed journals and scholarships including Myanmar. The paper is not a historical account of Myanmar's politics and conflict. However, based on the overwhelming 
evidence, the paper is inclined to the view that a prima facia case of atrocity crimes being committed exists in the context of Rakhine, Myanmar and aims to explore the process and mechanism to pursue justice.

\section{Atrocity Crimes Defined}

The collective wisdom of international community has identified three grave nature of crimes -- genocide, crimes against humanity and war crimes as the 'atrocity crimes'. ${ }^{7}$ The ambit of atrocity crimes was extended to include 'ethnic cleansing' following the pledge by all UN member states on the Responsibility to Protect (R2P) during the 2005 World Summit at UN General Assembly (UNGA). ${ }^{8}$ All these crimes are legally defined in different Conventions and Statute, in particular, the 1948 Convention on the Prevention and Punishment of the Crime of Genocide (hereafter Genocide Convention). The genocide is defined as any act committed with an intent to destroy, in whole or in part, a national, ethnical, racial or religious group. Such action may include (a) killing members of the group; (b) causing serious bodily or mental harm to members of the group; (c) deliberately inflicting on the group conditions of life calculated to bring about its physical destruction in whole or in part; (d) imposing measures intended to prevent births within the group; (e) forcibly transferring children of the group to another group. ${ }^{9}$ It recognises that, even though the victims of the crimes are individuals, they are targeted because of their membership, real or perceived, in one of the groups. The crimes against humanity encompass acts that are part of a widespread or systematic attack directed against any civilian population..$^{10}$ The Rome Statute lists eleven such crimes. These includes murder,

\footnotetext{
${ }^{7}$ Such grouping of atrocity crime emerged to facilitate public debate while reflecting its 'magnitude and character'. See David Scheffer, 'Genocide and Atrocity Crimes.' Genocide Studies and Prevention 1, 3: 229-250, (December 2006), p.237 and 'Framework of Analysis for Atrocity Crimes: A Tool for Prevention', http://www.un.org/en/preventgenocide/adviser/pdf/framework/, accessed 30 September 2017, pp.1-3

${ }^{8}$ See A/RES/60/1, 16 September 2005. p. 30.

${ }^{9}$ See Article II, The Genocide Convention.

${ }^{10}$ See Article 7, the 1998 Rome Statute of the International Criminal Court. Myanmar is not a state party to the Statute.
} 
extermination, enslavement, deportation/forcible transfer of population, imprisonment or other severe deprivation of physical liberty, torture, rape/sexual slavery/enforced prostitution/forced pregnancy/enforced sterilization/any other form of sexual violence of comparable gravity, political, racial, national, ethnic, cultural, religious persecution, enforced disappearance, crime of apartheid, other inhumane acts of a similar character intentionally causing great suffering, or serious injury to body or to mental or physical health. ${ }^{11}$ However, for an act to be regarded as a crime against humanity, the ultimate target must be the civilian population. Finally, War crimes are defined as crimes committed against combatants or non-combatants in international or non-international armed conflicts. ${ }^{12}$ In international armed conflicts, victims include those specifically protected by the four 1949 Geneva Conventions. ${ }^{13}$ In non-international armed conflicts, common Article 3 of the four Geneva Conventions affords protection to "persons taking no active part in the hostilities, including members of armed forces who have laid down their arms and those placed 'hors de combat' by sickness, wounds, detention, or any other cause". Additionally, it includes protection for the medical and religious personnel, humanitarian workers and civil defence staffs in both types of conflicts.

'Ethnic cleansing' does not have a legal definition. ${ }^{14}$ However, a working definition was first introduced by the UN Commission of Experts investigating the violations of international humanitarian law committed in the territory of former Yugoslavia (hereafter Commission of Experts). They defined ethnic cleansing as 'a purposeful policy designed by one ethnic or religious group to remove by violent and terror-inspiring means the civilian population of

\footnotetext{
${ }^{11}$ See Ibid.

${ }^{12}$ For details of war crimes see, Article 8, Ibid.

${ }^{13}$ Four Geneva Conventions accord protection to the (a) wounded and sick in armed forces in the field; (b) shipwrecked members of armed forces at sea; (c) prisoners of war; (d) civilian persons, including in occupied territory. Myanmar is party to all four Conventions since 25 August 1992.

14 See UN Office on Genocide Prevention and the Responsibility to Protect, 'Ethnic Cleansing', http://www.un.org/en/genocideprevention/ethnic-cleansing.html/, accessed 30 September 2017.
} 
another ethnic or religious group from certain geographic areas. ${ }^{15}$ The R2P document extends the realm of atrocity crimes to include ethnic cleansing requiring all states, regional organisations and the UN system 'to give a doctrinal, policy and institutional life' to prevent and respond to such crime. ${ }^{16}$ The acts codified as 'ethnic cleansing' are similar to acts listed as genocide and crime against humanity. It also include confinement of civilian population in ghetto areas, displacement and deportation, deliberate military attacks or threats of attacks on civilians and civilian areas, use of civilians as human shields, destruction of property, robbery of personal property, attacks on hospitals, medical personnel, and locations with the Red Cross/Red Crescent emblem.

Despite such well-defined boundaries, every mass killing evokes an emotive 'political' use of these terms. However, the political depiction of atrocity crimes is not necessarily conflicting and irreconcilable with the 'legal-empirical' depiction. The former is often a part of preventive strategy while the latter requires gathering systemic data, facts, and evidence leading to the indictment, prosecution, and trial of the perpetrators. The legal codification helps to separate the 'emotive-political' part and establish the 'empirical-legal' account. Thus, the difference between 'political' and 'legal' version collapses when the allegation of atrocity crimes is meticulously investigated, evidence are systematically recorded and documented to pursue justice. State actors with the capacity and willingness to ensure the rule of law and seek justice can provide such separation. But such ideal condition does not always exist. So what instruments and mechanisms are available to hold the state and the individuals accountable for atrocity crimes in case there is a lack of willingness and capacity?

\footnotetext{
${ }^{15}$ See S/1994/674, 27 May 1994, p.33.

${ }^{16}$ Several UN documents highlight the implementations strategy of the R2P to protect the populations from atrocity crimes. See A/63/677, 12 January 2009, p.4.
} 


\section{State Responsibility}

According to the Genocide Convention, a state and/or its organs may be held accountable for committing genocide. State's responsibility stems not only from its direct involvement but also from failing to prevent any of its organs from committing acts of genocide. ${ }^{17}$ Some international instrument such as the R2P is not legally binding but facilitate invoking the genocide doctrine against a state. It provides an accepted and coherent set of frameworks to guide effective international response to imminent or occurring atrocity crimes. ${ }^{18}$ The R2P provisions are based on two core principles. First, upholding the sovereignty norm, R2P recognise that the primary responsibility for preventing atrocity crimes lies with the state. Second, if the state is unable/unwilling to stop such crime, the principle of non-intervention yields to the international community's responsibility to protect. ${ }^{19}$ State that has 'manifested failed' to protect its population can face a 'timely and decisive' external intervention. The R2P document suggests a 'large-scale ethnic cleansing, when carried out by killing, forced expulsion, acts of terror or rape', would constitute a valid condition at which state's sovereignty may yield to the international community. The nature of intervention could be diplomatic, humanitarian, coercive sanction or in extreme cases military action, often to establish 'safe zones' to save lives. ${ }^{20}$ Viewed these way, the R2P provisions appears not an abrogation of state's sovereignty, but a commitment and resolve of the global community to protect humanity

\footnotetext{
${ }^{17}$ See Article I of the Genocide Convention and Alina Lindblom, Elizabeth Marsh, Tasnim Motala, and Katherine Munyan, Persecution of The Rohingya Muslims: Is Genocide Occurring in Myanmar's Rakhine State? A Legal Analysis, International Human Rights Clinic, Yale Law School, October 2015; and Crimes in Burma, International Human Rights Clinic, Harvard Law School.

${ }^{18}$ Seven UNSC Resolutions between 2006-16 refers to R2P provisions. See Global Centre for Responsibility to Protect, http://www.globalr2p.org/, accessed 3 October 2017.

${ }^{19}$ See International Commission for Intervention and State Sovereignty (ICISS), The Responsibility to Protect (Ottawa: IDRC, 2001), pp. xii-xiv.

${ }^{20}$ According to R2P provisions, the military option is an 'exceptional and extraordinary measure' and can only be justified to prevent 'serious and irreparable harm' such as large-scale loss of life, 'ethnic cleansing' occurring or imminently likely to happen. See Ibid, p. xii.
} 
and to strengthen host nation's capacity and willingness to prevent irreparable harm and large-scale loss of life of its population.

However, the R2P is also viewed as an 'interventionist' political instrument. ${ }^{21}$ Such a view owes to its selective use and practical challenges. Establishing that the state has 'manifested failed' to protect its population is almost always contested. Evidence presented in the UNSC to invoke R2P provisions in the past have been found to be partial, conflated or conflicting. The UNSC public debate on Rohingya issue on 29 September 2017 also contained a competing account of the issue. The statement by the Russian envoy did not have any mention of the acts by Myanmar security forces and their supporting militias as documented in the reports, satellite images, and statements of the victims by the UN agencies, right groups, and credible media. ${ }^{22}$ Echoing Myanmar's statement, the Russian envoy only cited the attack by the Arakan Rohingya Salvation Army (ARSA) on security forces and blamed them for 'massacre of civilians' and arson attacks 'on entire villages'. ${ }^{23}$ He also suggested being 'very precise' while terming the crisis as 'genocide' and 'ethnic cleansing'.

The selective choice of evidence at the UNSC reflects the challenge of attributing political responsibility. It leads to inconsistent and uneven decision making by the UNSC resulting rare and controversial enforcement of the R2P. ${ }^{24}$ It also weakens the normative legitimacy of the

\footnotetext{
${ }^{21}$ Recognizing the historical failures of the UNSC, R2P document notes, '.. faced with conscienceshocking situations, [UNSC] failed to respond as it should have with timely authorisation and support'. See Ibid, p. 70. Also, see David Chandler, 'The Responsibility to Protect? Imposing the 'Liberal Peace', International Peacekeeping, 11 (1): 59-81 (2004), pp.65-68. Phillip Cuncliffe, 'A dangerous Duty: Power Paternalism and the Global Duty of Care', Critical Perspectives on the Responsibility to Protect: Interrogating Theory and Practice, (New York: Routledge, 2011), pp. 51-70.

${ }^{22}$ See, Jonathon Head, 'Who is burning down the Burmese Villages?

${ }^{23}$ See S/PV.8060, 28 September 2017, p.15.

${ }^{24}$ The inconstancy on implanting R2P was most evident in Darfur and Syria. See Gareth Evans and Mohamed Sahnoun, 'The Responsibility to Protect', Foreign Affairs, November/December (2002) and Neville F. Dastoor, 'The Responsibility to Refine: The Need for a Security Council Committee on the Responsibility to Protect', Harvard Human Rights Journal 25, (2009), p.31.
} 
R2P making it challenging to hold the state actors accountable. Thus, harnessing the political will of the key state actors to end impunity is the first challenge as it allows to focus on the criminal responsibility of the perpetrators and their commanders to pursue justice.

\section{Individual and Command Responsibility}

Most human rights instruments focus on individuals rather than the state to prevent atrocity crimes. For example, Article IV of the Genocide Convention focuses on persons irrespective of their status, as it states: 'Persons committing genocide or any of the other acts enumerated in article III shall be punished, whether they are constitutionally responsible rulers, public officials or private individuals.' (Italic added). Article $\mathrm{V}$ of the same Convention underpins the criminal liability of individuals, requiring States 'to enact necessary legislation' to provide 'effective penalties for persons guilty of genocide or any of the other acts enumerated in article III. ${ }^{25}$ Thus, provisions to hold individuals criminally liable for the commission of such offence is fundamental to the definition of atrocity crimes, in addition to imposing state responsibility that would enable their prosecution in a Court duly constituted for such purpose. ${ }^{26}$

Establishing command responsibility is also integral to deter atrocity crimes and requires establishing the criminal-intent of individual commanders. ${ }^{27}$ However, in most cases, the political or military leadership denies their knowledge about their subordinates and what they were doing at a particular time. Thus, it is necessary to gather both generic and specific information on 'what the commander knew and what s/he did' with that information. The

\footnotetext{
${ }^{25}$ The acts under Article III of the Genocide Convention are: (a) Genocide; (b) Conspiracy to commit genocide; (c) Direct and public incitement to commit genocide; (d) Attempt to commit genocide; (e) Complicity in genocide.

${ }^{26}$ This attribute is considered as one of the five defining characteristics of atrocity crimes. See David Scheffer, Genocide and Atrocity Crimes, p. 239.

${ }^{27}$ This was stressed in the Commission of Experts Report. Please see Article 28 of the Rome Statute and S/1994/674, 27 May 1994, pp.16-27.
} 
Commission of Experts outlined 12 indices ${ }^{28}$ to determine command responsibilities. These include the (i) number of illegal acts; (ii) type of illegal acts; (iii) scope of illegal acts; (iv) time during which the illegal acts occurred; (v) number and type of troops involved; (vi) logistics involved, if any; (vii) geographical location of the acts; (viii) widespread occurrence of the acts; (ix) tactical tempo of operations; (x) modus operandi of similar illegal acts; (xi) officers and staff involved; (xii) location of the commander at the time. Such information is critical to determine the criminal-intent of the commander and help in deciding the command responsibility during any prosecution.

The emphasis on the individual's criminal liability is evidenced by the mandates of the ICTs for the trial of atrocity crimes committed in former Yugoslavia (ICTY), Rwanda (ICTR), Sierra Leone (SCSL) and Cambodia (ECCC). The ICTR was mandated to 'prosecute individuals for the crime committed in the territory of Rwanda and neighbouring States. ${ }^{29}$ Similarly, the focus of Special Court for Sierra Leone (SCSL) was to prosecute 'persons who bear greatest responsibilities' for the grave violation of international humanitarian law and SL law. ${ }^{30}$ The mandate of the Extraordinary Chambers in the Courts of Cambodia (ECCC) was for the trial of 'senior leaders and those most responsible' for atrocity crimes committed during the period of Democratic Kampuchea. ${ }^{31}$ The focus on individual and command responsibility, as opposed to the 'state', facilitated serving justice to 252 people through these four ICTs (see table 1). ${ }^{32}$

\footnotetext{
${ }^{28}$ The doctrine of command responsibility primarily applies to military/paramilitary commanders but may also involve against political leaders and public officials. See Ibid, pp.17-18.

${ }^{29} \mathrm{See}$ 'The ICTR in Brief', http://unictr.unmict.org/en/tribunal, accessed 23 September 2017. The ICTR operation ended on 31 December 2015.

${ }^{30} \mathrm{SCSL}$ is considered a 'hybrid court' as it involves national and the international elements. See 'Impact and Legacy Survey for the SCSL', http://www.rscsl.org/, accessed 4 October 2017.

${ }^{31}$ See 'Key Events', https://www.eccc.gov.kh/en/about-eccc/introduction/, accessed 4 October 2017.

${ }^{32}$ The data covers up to 15 October 2017. In 2010, UN established the Mechanism for International Criminal Tribunals (MICT), formally referred to as the International Residual Mechanism for Criminal Tribunals, with a mandate to perform a few essential functions previously carried out by the ICTR and ICTY. There are 85 cases involving 117 individuals who await trial and sentencing in MICT. See http://www.unmict.org/en, accessed 15 October 2017.
} 
'Atrocity Crimes' in Myanmar - is there Political Will?

Table 1: Summary of Justice Served by the Four ICTs (number of individuals)

\begin{tabular}{|l|c|c|c|c|c|}
\cline { 2 - 6 } \multicolumn{1}{c|}{} & ICTY & ICTR & SCSL & ECCC & Total \\
\hline Indicted/Charged & 161 & 93 & 13 & 15 & 282 \\
\hline Proceedings concluded & 154 & 85 & 10 & 3 & 252 \\
\hline Ongoing & 7 & 0 & 0 & 3 & 10 \\
\hline Acquitted & 19 & 14 & 0 & - & 33 \\
\hline Transferred to State Jurisdiction & 13 & 5 & - & - & 18 \\
\hline Fugitive/At-large & 0 & 8 & 1 & - & 9 \\
\hline $\begin{array}{l}\text { Indictment Terminated/ } \\
\text { Withdrawn/Died or illness }\end{array}$ & 37 & 8 & 3 & 3 & 51 \\
\hline Suspects yet to be Charged & 0 & 0 & 0 & 6 & 6 \\
\hline
\end{tabular}

Source: Author's compilation from ICTY, ICTR, SCSL, and ECCC official websites.

In sum, attribution of state's political responsibility for atrocity crimes appears more challenging compared to the attribution of criminal responsibility. It begs to explore the mechanism and process of establishing the four ICTs to establish the ICTM-R. However, any such investigation of the mechanism and process needs to start with the examination of the 'mind' of the state, particularly on the human rights issues-- discussed next.

\section{Reading the 'Mind' of Myanmar and the Global Instruments on Atrocity Crimes}

The 'mind' of the state about any global norm is often reflected by its commitment and compliance of the relevant global instruments on atrocity crimes. ${ }^{33}$ As a collective social entity embedded in global societies of states, state's ratifications, declarations/reservation on ratifications and interactions with the relevant global institutions captures its mind. Thus, we focus on the ratification and declaration made by the Government of Myanmar (GoM) on

\footnotetext{
${ }^{33}$ Even though ratifications of a global instrument can be 'cosmetic' and/or under pressure, the ratification and declarations/reservation made during ratifications, constitute the refection of state's 'mind'. See for Anja Jetschke and Andrea Liese, 'The power of human rights a decade after: from euphoria to contestation?' , pp. 26-42 and Ann Marie Clark, 'The normative context of human rights criticism: treaty ratification and UN mechanisms', pp 125-145, in Thomas Risse, Stephen C. Ropp and Kathryn Sikkink (eds.), The Persistent Power of Human Rights: From Commitment to Compliance, (Cambridge: Cambridge University Press, 2013).
} 
relevant global instruments and the formal reports and replies to those reports on human rights situations by the GoM at the UN.

\section{Trends in Ratification and Reservation}

Myanmar acceded to only five Conventions and one Protocol (see table 2) relating to the atrocity crimes and human right issue (see Annex A for the list of international human rights instruments). GoM's ratification trend of human rights instruments is significantly at odds with its ratification of Counter-Terrorism (CT) instruments. Before 2001, the GoM was party to four CT and human rights instruments each. After 2001, the GoM formed a 'study group' to examine remaining CT conventions to ratify those ${ }^{34}$ by 2006 , it became a party to five more CT Conventions and ratified ten CT Convention by $2017 .{ }^{35}$ In contrast, GoM ratified only one human rights Convention during this period. Myanmar's response and preference to ratify coercive Conventions over human rights arguably reflects its 'mind'.

Table 2: Relevant International Instruments Ratified/Accessed by Myanmar

\begin{tabular}{|c|c|c|}
\hline International Instruments & $\begin{array}{c}\text { Ratified/ } \\
\text { Accessed/ Signed }\end{array}$ & $\begin{array}{l}\text { Declaration/ } \\
\text { Reservation }\end{array}$ \\
\hline $\begin{array}{l}\text { Convention on the Prevention and Punishment of the Crime of } \\
\text { Genocide }\end{array}$ & Accession in 1956 & $\begin{array}{l}\text { Article VI \& } \\
\text { VIII }\end{array}$ \\
\hline Geneva Conventions (I -IV) & Accession in 1992 & \\
\hline $\begin{array}{l}\text { Convention on the Elimination of All Forms of Discrimination } \\
\text { against Women (CEADW) }\end{array}$ & Accession in 1997 & Article 29 \\
\hline Convention on the Rights of the Child & Accession in 1991 & $\begin{array}{l}\text { Withdrew in } \\
1993\end{array}$ \\
\hline Convention on the Rights of Persons with Disabilities & Accession in 2011 & - \\
\hline $\begin{array}{l}\text { Optional Protocol to the Convention on the Rights of the Child } \\
\text { on the Sale of Children, Child Prostitution, and Child } \\
\text { Pornography }\end{array}$ & Accession: 2012 & - \\
\hline
\end{tabular}

Source: Author's compilation from UN Treaty Collection database

\footnotetext{
${ }^{34}$ See S/2001/1144, 10 December 2001, p.3.

${ }^{35}$ Remaining CT instruments includes Nuclear Terrorism Convention and two Protocols. See UN Treaty Collection Database.
} 
A comparison of the issues on which states expressed reservations provide a more nuanced picture. Table 3 lists the state parties and the Articles of Genocide Convention on which they showed reservation. Most reservations relate to involving the International Court of Justice (ICJ) (Article IX). However, Myanmar's reservations were on engaging International Penal Tribunal (IPT) (Article VI) and competent UN organs (Article VIII) for the trial, prevention, and suppression of genocide. GoM is the only amongst the 148 signatories who declined to engage UN organs under this Convention.

Table 3: Declarations/Reservation by the Signatory States on 1948 Genocide Convention

\begin{tabular}{|c|l|l|}
\hline $\begin{array}{c}\text { Article } \\
\text { Article } \\
\text { VI }\end{array}$ & $\begin{array}{l}\text { What the Article says } \\
\text { 'Persons charged with genocide...shall be tried by a competent } \\
\text { tribunal of the State..., or by such international penal tribunal } \\
\text { as may have jurisdiction with respect to those Contracting } \\
\text { Parties which shall have accepted its jurisdiction.' }\end{array}$ & $\begin{array}{l}\text { Algeria, Morocco, Myanmar, } \\
\text { Philippines, USA, Venezuela }\end{array}$ \\
\hline $\begin{array}{c}\text { Article } \\
\text { VII }\end{array}$ & $\begin{array}{l}\text { Genocide and the other acts enumerated in article III shall not } \\
\text { be considered as political crimes for the purpose of } \\
\text { extradition. The Contracting Parties pledge themselves in such } \\
\text { cases to grant extradition in accordance with their laws and } \\
\text { treaties in force. }\end{array}$ & $\begin{array}{l}\text { Malaysia, } \\
\text { Venezuela }\end{array}$ \\
\hline Article \\
VIII
\end{tabular} $\begin{aligned} & \text { Contracting party can call upon the 'competent organs of the } \\
& \begin{array}{l}\text { UN to take such action under the Charter of the UN as they } \\
\text { consider appropriate for the prevention and suppression of acts } \\
\text { of genocide or any of the other acts enumerated in article III.' }\end{array}\end{aligned}$

Source: Author's compilation from United Nations Treaty Collection database.

Table 4 lists the nature of the reservations on Article VI to provide more insight to comprehend GoM's 'mind'. As evident, Morocco and Algeria accept the provision to engage the IPT for atrocity crimes under 'exceptional' circumstances; the USA and Philippines also do not reject but attach preconditions to accept the jurisdiction of the IPT. In contrast, Myanmar and Venezuela stand out as the only two countries refusing any jurisdiction of the IPT. Again, 
contrary to the most states, Myanmar accepted Article IX, which allows involving ICJ to address disputes between state parties. Mentionable that Myanmar had rejected to involve ICJ for dispute settlement while ratifying the Convention to Eliminate all kinds of Discrimination against Women (CEDAW, Article 29).

\section{Table 4: Declaration/Reservations by Countries on Article VI of 1948 Genocide Convention}

Myanmar. Nothing contained in the said Article shall be construed as depriving the Courts and Tribunals of the Union of jurisdiction or as giving foreign Courts and tribunals authority over any cases of genocide or any of the other acts enumerated in article III committed within the Union territory.

Algeria. International tribunals may, as an exceptional measure, be recognised as having jurisdiction, in cases in which the Algerian Government has given its express approval.

Morocco: May be admitted exceptionally in cases for which the Moroccan Government has given its specific agreement.

The Philippines. Nothing contained in said articles shall be construed as depriving Philippine courts of jurisdiction over all cases of genocide committed within Philippine territory save only in those cases where the Philippine Government consents to have the decision of the Philippine courts reviewed by either of the international tribunals referred to in said articles.

The USA. Reserves the right to effect its participation in any such [international] tribunal only by a treaty entered into specifically for that purpose with the advice and consent of the Senate.

Venezuela. Any proceedings to which Venezuela may be a party before an international penal tribunal would be invalid without Venezuela's prior express acceptance of the jurisdiction of such international tribunal.

Source: Authors compilation from the UN Treaty Collection.

\section{Interaction with the UN CEADW Committee}

Myanmar's communication with the UN CEADW Committee (hereafter Committee) also indicates regime's 'mind' and outlook. The GoM submitted five periodic reports to the Committee. ${ }^{36}$ This can be viewed as positive engagement. However, the Committee's Final Recommendations notes several systemic obstacles to human rights situation in the context of Rakhine, such as, limitations of the parliament's legislative power, legal and nationality status, widespread gender-based violence, limited access to justice, visibility and participation in political and public life, education and employment opportunities ${ }^{37}$ The Report also observed

\footnotetext{
${ }^{36}$ The combined 4th and $5^{\text {th }}$ Report was filed in 2015. See CEDAW/C/MMR/4-5, 2 March 2015. Also see CEDAW/C/SR.1407, 12 July 2016.

${ }^{37}$ See CEDAW/C/MMR/CO/4-5, 25 July 2016, pp.4-8, 10, 14-15.
} 
the lack of "comprehensive law guaranteeing protection against forced displacement or programmes...in particular those belonging to ethnic minority groups such as the Rohingya. ${ }^{38}$ Mentionable that the Final Recommendations were made after due deliberation and consultation of the reports from the GoM and different CSOs in Myanmar. The CSOs who submitted reports to the Committee includes Amnesty International, ${ }^{39}$ CEDAW Action Myanmar (CAM) ${ }^{40}$ Christian Solidarity Worldwide (CSW) ${ }^{41}$, Global Justice Centre (GJC) and Gender Equality Network (GEN), ${ }^{42}$ Karen Human Rights Group (KHRG), ${ }^{43}$ Landesa and Namati, ${ }^{44}$ The Arakan Project ${ }^{45}$, Women Peace Network - Arakan (WPN-A) ${ }^{46}$, Women's

\footnotetext{
${ }^{38}$ See Ibid, p. 14.

${ }^{39}$ See Amnesty International, '64th Pre-sessional Working Group: The Republic of the Union of Myanmar - Information on 'Race and Religion Protection' Laws and situation of Women Human Rights Defenders (WHRDS),' 29 September 2015, http://tbinternet.ohchr.org/Treaties/CEDAW/Shared\%20Documents/MMR/INT_CEDAW_NGO_MM R_21795_E.pdf/, accessed 5 October 2017.
}

${ }^{40}$ See CAM, 'Shadow Report on Thematic Issues: Violence against Women to 64th Session of UN CEDAW Committee In relation to Myanmar Combined $4^{\text {th }} \& 5^{\text {th }}$ Periodic Report ', 23 February 2015, http://tbinternet.ohchr.org/Treaties/CEDAW/Shared\%20Documents/MMR/INT CEDAW NGO MM R 24427 E.pdf/, accessed 7 October 2017.

${ }^{41}$ See CSW, 'CEDAW Committee 64th session - Stakeholder Submission' June 2016. http://tbinternet.ohchr.org/Treaties/CEDAW/Shared\%20Documents/MMR/INT_CEDAW_NGO_MM R_24254_E.pdf/, accessed 7 October 2017.

${ }^{42}$ GJC \&GEN, 'Shadow Report on Myanmar for the $64^{\text {th }}$ Session of the CEDAW Committee July 2016' http://tbinternet.ohchr.org/Treaties/CEDAW/Shared\%20Documents/MMR/INT_CEDAW_NGO_MM R_24273_E.pdf/, accessed 7 October 2017. And Global Justice Centre, 'Promises Not Progress: Burma's National Plan for Women Falls Short of Gender Equality and CEDAW', http://tbinternet.ohchr.org/Treaties/CEDAW/Shared\%20Documents/MMR/INT CEDAW NGO MM R_21890_E.pdf/, accessed 7 October 2017.

${ }^{43}$ See KHRG, 'Submission for the 64th session of the Committee on CEDAW, Myanmar, July 2016', http://tbinternet.ohchr.org/Treaties/CEDAW/Shared\%20Documents/MMR/INT_CEDAW_NGO_MM R 24239 E.pdf/, accessed 6 October 2017.

${ }^{44}$ Namati and Landesa, 'Recommendations for Implementation of Pro-Poor Land Policy and Land Law in Myanmar: National Data and Regional Practices October 2015', http://tbinternet.ohchr.org/Treaties/CEDAW/Shared\%20Documents/MMR/INT_CEDAW_NGO_MM R_21937_E.pdf/, accessed 7 October 2017.

${ }^{45}$ The Arakan Project, 'Key Issues Concerning the Situation of Stateless Rohingya Women and Girls in Rakhine State, Myanmar, Submission to the Committee on CEDAW for the Examination of the combined 4th and 5th periodic State Party Reports Myanmar, 10 June 2016', http://tbinternet.ohchr.org/Treaties/CEDAW/Shared\%20Documents/MMR/INT_CEDAW_NGO_MM R_24280_E.pdf/, accessed 7 October 2017.

46 See WPN-A, 'Observations and Topics to be Included in the List of Issues', http://tbinternet.ohchr.org/Treaties/CEDAW/Shared\%20Documents/MMR/INT_CEDAW_NGO_MM R 21938 E.pdf/, accessed 7 October 2017. And WPN- A, 'Submission to the 64th Session CEDAW Committee for Consideration of Myanmar's Combined Fourth and Fifth Periodic Reports', June 2016, 
League of Burma ${ }^{47}$, and Myanmar National Human Rights Commission (MNHRC). ${ }^{48} \mathrm{~A}$ summary of the recommendations related to the Rohingyas from the CSO's shadow reports is in annex B. The Anan Commission Report, submitted before the current spate of violence, also notes episodes of serious human rights violations by the security force and recommends holding the perpetrators accountable. ${ }^{49}$

The GoM replied to the Committee's Final Recommendations stating that 'the people of Myanmar do not recognise the term "Rohingya" which has never existed in Myanmar ethnic history. ${ }^{50}$ It also requested the Anan Commission for not using the term 'Rohingya'. As a result, the Commission's report does not use the term 'Bengali' or 'Rohingya', and refer them as 'Muslims' or 'the Muslim community in Rakhine'. ${ }^{51}$ The denial of an ethnic group appears contrary to Myanmar's constitutional provisions that guarantees 'non-discrimination based on race, birth, religion, official position, status, culture, sex and wealth.' 52

In sum, Myanmar's minimalist ratification of human rights related instruments and the declarations reflects its protective mind aimed to insulate the GoM from external scrutiny. Notwithstanding such limitations, an optimistic interpretation of the evidence, such as GoM's

http://tbinternet.ohchr.org/Treaties/CEDAW/Shared\%20Documents/MMR/INT_CEDAW_NGO_MM R 24229 E.pdf/, accessed 7 October 2017.

${ }^{47}$ See WLB, 'Shadow Report on Burma for the 64th Session of the Committee on CEDAW' http://tbinternet.ohchr.org/Treaties/CEDAW/Shared\%20Documents/MMR/INT CEDAW NGO MM R_24233_E.pdf/, accessed 7 October 2017. And WLB, 'Annex to the Shadow Report on Burma for the 64th Session of the Committee on the Elimination of Discrimination against Women', http://tbinternet.ohchr.org/Treaties/CEDAW/Shared\%20Documents/MMR/INT_CEDAW_NGO_MM R 24233 E.pdf/, accessed 8 October 2017.

${ }^{48}$ MNHCR, A Report to the UN Committee on the Elimination of Discrimination against Women.

49 Kofi Anan, 'Final Report of the Advisory Commission on Rakhine State', August 2017, http://www.rakhinecommission.org/app/uploads/2017/08/FinalReport_Eng.pdf, accessed 16 October 2017, p. 55.

50 See CEDAW/C/MMR/Q/4-5/Add.1 p.13.

${ }^{51}$ Kofi Anan, 'Final Report of the Advisory Commission on Rakhine State, p. 12

${ }^{52} \mathrm{See}, \mathrm{CEDAW} / \mathrm{C} / \mathrm{MMR} / \mathrm{Q} / 4-5 /$ Add.1, p.2. 
willingness to remain engaged with the UN CEDAW Committee and the legal acceptance of Article IX of the Genocide Conventions, hints at the possibility to discuss and engage the ICJ in addressing the Rohingya issue by the affected states to pursue justice. With these insights about the applicability of global instruments in Myanmar context, let us now turn to the process and mechanism of different ICTs to explore the pathways for accountability.

\section{Pathways of Accountability: Establishing the ICTM-R}

Each context of the four ICTs was unique. The Myanmar context also differs as the country is not housing any UN troops. More importantly, it is under 'disciplined democracy' where the military continues to be in the centre of political power despite having an elected civilian government. ${ }^{53}$ Such contrasts, however, do not restrict us to explore the process and mechanism to arrive at some general conclusions to establish the ICTM-R. The broad focus is to find the potential pathways that will enable GoM to end the culture of impunity and facilitate harnessing the domestic and international political will to pursue justice.

Table 5 provides a brief comparison of the mandate, political will, ${ }^{54}$ and host country's ratification of key global instruments that are vital to the process of establishing ICTs. Political will is captured by analysing the votes, statements, and initiatives taken by the external actors during the process of establishing the ICTs (international political will) ${ }^{55}$ and the host state's degree of consent to the composition and functioning of the Court (national political will). The

53 See, Marco Bünte, 'Burma's Transition to "Disciplined Democracy": Abdication or Institutionalization of Military Rule?' GIGA Working Papers No 177, August 2011. Casy Cagley, “"Disciplined Democracy" - Lessons for Cuba from Myanmar', Open Democracy, 4 October 2016.

${ }^{54}$ Political will in this context is narrowly defined as the 'the determination of an individual political actor to do and say things that will produce the desired outcome. See Appendix 3. Understanding 'Political Will'. (2004) p.1. https://assets.publishing.service.gov.uk/media/.../R8236Appendix3.pdf/, accessed 11 February 2018.

${ }^{55}$ Includes but not limited to the statement/letters by Mexico (S/25417), Canada (S/25504 and S/25594, S/25765), Russia (S/2553, S/25829), Brazil (S/25540), USA (S/25575, S/25829); Slovenia (S/25652); Netherlands (S/25716), France, UK, Spain (S/25829), Uganda (S/1994/1230) to the UN. 
regional and extra-regional actors provided qualified support when acting under Chapter VII, particularly on the issue about the jurisdiction of the Court (See Annex C for more details). For example, in the case of ICTR, Uganda expressed reservation about the concurrent, territorial and temporal jurisdiction (Article 7 and 8 ) of the Court stating that it 'considers that its [Ugandan] judicial system has primary and supreme jurisdiction and competence over any crimes committed on Ugandan territory by its citizens or non-citizens, at any particular time, 56 Mentionable that China abstained from voting in ICTR and suggesting the resolution must have a domestic legal foundation.

${ }^{56}$ See S/1994/1230, 31 October 1994, p. 1. 
Table 5: Comparison of the nature and process of establishing the ICTY, ICTR, SCLS, and ECCC.

$$
\text { ICTY ICTR SCLS }
$$

ECCC

1. Mandate: nature and limits

Prosecute persons responsible for Prosecute individuals for the crime Prosecute persons who bear greatest specific crimes committed since January 1991 in the territory of the former Yugoslavia. responsibilities for the grave violation of international humanitarian law and SL law during the civil war after 30 Nov 1996.

2. Political Will (international): What UN instrument formally initiated the process of establishing the Court and how did the UNSC vote?

Acting under Chapter VII, the UNSC unanimously (15-0) adopted Resolution 827 (1993).
Acting under Chapter VII, the UNSC adopted (13-1-1) Resolution 955 (1994) China: abstained, Rwanda: against.
The UNSC unanimously (15-0) adopted Resolution 1315 (2000).

Economic Community of West African States (ECWAS) was supportive.

3. Political Will (domestic): Consent and Involvement by the host nation in the Court composition and establishment

Unwilling acceptance. All 14 Permanent $\quad$ Voted against despite requesting to $\quad$ Willing. Requested to set up SCSL in Judges appointed by the UNGA and UNSC (Ad-litem). Court located outside the host country. set up the Court with temporal light of the Lomé Peace Agreement

作 1994. All judges appointed by UN.

Court located in Arusha, Tanzania. country (initially); appoints $6 / 16$ judges.
Commission on HR Resolution 1997/49, (1997); UNGA Resolution A/RES/ 52/135 (1997) A/ RES/ 53/145, (1999)

\section{Party to Key International Instruments on Atrocity Crimes: Ratification/accession} (i) 1948 Genocide Convention

Ratified in August 1950 (Former

Yugoslavia)

Accession in 1975 (reservations on

Not a party

Crimes committed between 17 April 1975 to 6 January 1979 by the senior leaders and those who are most responsible in Democratic Kampuchea.

Willing and reauested to setup ECCC.

Willing and requested to setup ECCC. Passed the ECCC Law \& signed MoU with the UN. The Court is in the host country; appoints 3/5 Pre-trial/Trial and 4/7 Supreme Court Chamber judges.

\begin{tabular}{ll|l|l} 
& (ii) 1949 Geneva Conventions and Protocols & & \\
Bosnia \& Herzegovina (Dec 1992) & Convention (May 1964), Protocol I \& & Convention (June 1965), Protocol I \& & Convention (Dec 1958), Protocol I \& \\
Croatia (May 1992) Serbia (Oct 2001) & II (Nov 1984) & II (Oct 1986) & II (Jan 1998)
\end{tabular} (iii) Acceptance of the Competence of the International Fact-Finding Commission according to article 90 of Additional Protocol I

Bosnia \& Herzegovina (Dec 1992), Party since July $1997 \quad$ Not a party

Croatia (May 1992), Serbia (Mar 2001)

(iv) 1998 Statute of the International Criminal Court

Bosnia \& Herzegovina (Apr 2002); $\quad$ Not a party $\quad$ Party since Sep 2000 Party since Apr 2002.

Croatia (May 2002), Serbia (Sep 2001)

Source: Author's compilation from the official websites of ICTY, ICTR, SCSL, ECCC, and UN Treaty Collection Database. 
Pathways to Justice for 'Atrocity Crime' in Myanmar - is there Political Will?

Table 6: Potential Pathways of Establishing ICM-R

The analysis leads to outline three potential pathways to establish the ICTM-R as shown in table 6. It reveals that although a convergence of domestic and international willingness is ideal and desirable, the domestic political will is a necessary but not sufficient condition to establish ICTs. Acting under Chapter VII, the UNSC can establish ICTs even when the host state is unwilling and locate the Court outside the host country. Tribunal based only on domestic willingness may suffer from legitimacy and neutrality deficits evidence by the ECCC (see Annex C). Table 5 also reveals that host nation's involvement in ICTs has expanded over time leveraging the 'principles of complementarity.' The findings beg the question: how do we harness the international and domestic political will to arrive at a consensus mandate?

\section{Harnessing International Political Will}

Analysing 'political will' entails identifying the relevant actors and the incentives/disincentives faced by the political actor(s) who is/are in the position of initiating a possible action(s) and those faced by other political actors who might support or oppose that/ those action(s). ${ }^{57}$ Material incentives such as bi-lateral official development assistance (ODA), foreign direct investments (FDI) and disincentives such as sanctions and embargoes are often regarded as

${ }^{57}$ See, Understanding 'Political Will'. (2004) p.2. 
Pathways to Justice for 'Atrocity Crime' in Myanmar - is there Political Will?

national instruments, reflecting actor's political will, particularly in the absence of a consensus.

Failing to achieve an agreement in the UNSC, the U.S. resorted to the Global Magnitsky Act and sanctioned the military commander who oversaw the operation in Rakhine. ${ }^{58}$ The European Union (EU) extended its sanctions on 'sale, supply, transfer or export of arms and related material' and provision of technical assistance, brokering and financing services to Myanmar military' to till 30 April $2018 .^{59}$ However, Myanmar survived harsher sanctions in the past. Until 2013, the EU sanctions included 936 entities and 564 individuals (see Figure 1). The U.S. imposed similar sanctions but removed 111 entities and individuals from its Specially Designated Nationals and Blocked Persons (SDN) list in $2016 .{ }^{60}$

Figure 1: EU Sanctions on Myanmar Till 2013

(Number of Entities and Individuals)

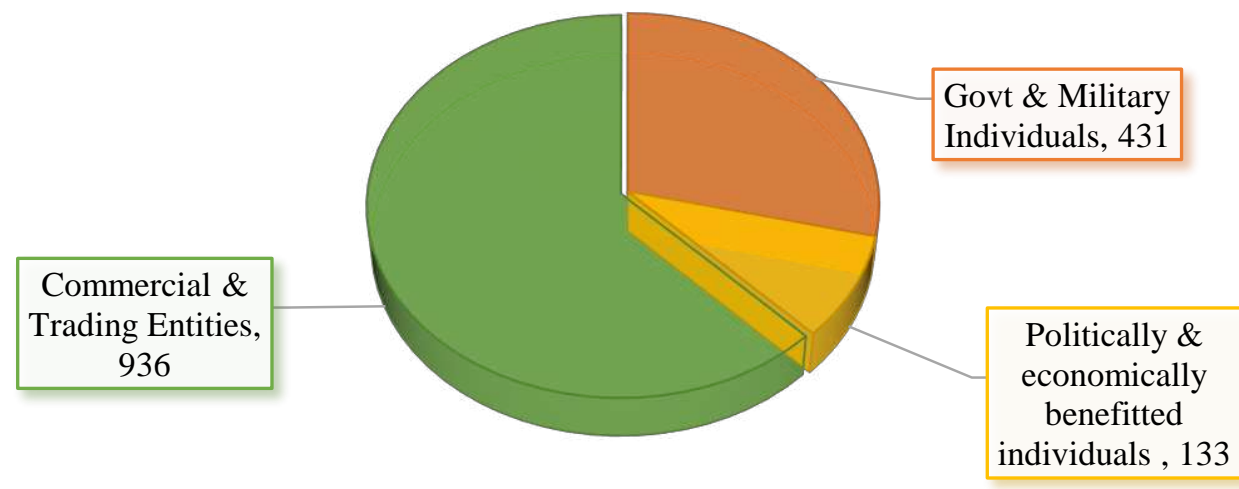

Source: Author's compilation from Annex I - V of Council Decision 2010/232/cfsp 26 April 2010.

\footnotetext{
${ }^{58}$ The U.S. also has a long-standing arms embargo. See 'Issuance of Global Magnitsky Executive Order; Global Magnitsky Designations', 21 December 2017, https://www.treasury.gov/resourcecenter/sanctions/OFAC-enforcement/Pages/20171221.aspx/ (accessed 25 December 2017)

${ }^{59}$ See Council Decision 2013/184/CFSP of 22 April 2013, http://eur-lex.europa.eu/legalcontent/EN/TXT/PDF/?uri=OJ:L:2013:111:FULL\&from=EN/ (Accessed 25 December 2017) and Council Decision (CFSP) 2017/734 of 25 April 2017, http://eur-lex.europa.eu/legalcontent/EN/TXT/PDF/?uri=CELEX:32017D0734\&from=EN/ (Accessed 25 December 2017)

${ }^{60}$ See 'Unblocking of Specially Designated Nationals and Blocked Persons Resulting From the Termination of the National Emergency and Revocation of Executive Orders Related to Burma', https://www.federalregister.gov/documents/2016/10/31/2016-26124/unblocking-of-speciallydesignated-nationals-and-blocked-persons-resulting-from-the-termination-of/ (accessed 25 Dec 2017)
} 
Pathways to Justice for 'Atrocity Crime' in Myanmar - is there Political Will?

Figure 2 compares the FDI and ODA flow to Myanmar and Cambodia for 2000-2015. The flow of external assistance to Cambodia closely parallels country's endorsements to key instruments to establish the ECCC. In case of Myanmar, it is paralleled mainly by its reforms towards 'disciplined democracy' and cyclone Nargis. The lifting of the sanctions after 2010 sharply increased the aid and FDI flow to Myanmar till reaching a decline. However, it remains well above the pre-2010 figures. This evidence tends to suggest a link between the political will of external actors to the domestic context.

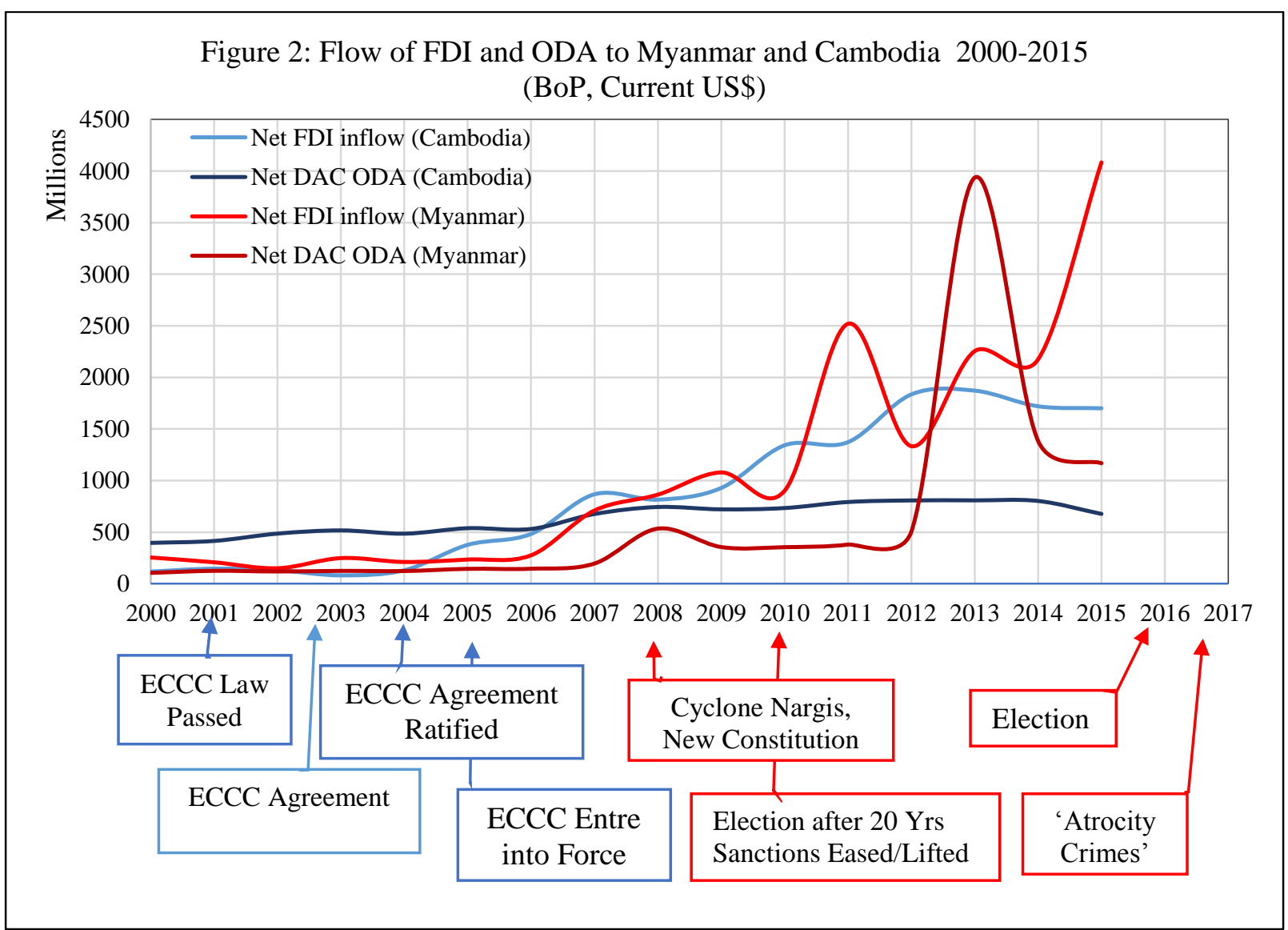

Source: Author's compilation from World Development Index Data.

Figure 3 breaks down the ODA to Myanmar concerning top 20 donors to identify critical actors.

The 'political will' of these donors in general and Japan in particular, to pursue justice for the atrocity crimes is crucial - particularly in the absence of the Chinese and Russian support. 
Pathways to Justice for 'Atrocity Crime' in Myanmar - is there Political Will?

Figure 3: Top 20 Donors of ODA to Myanmar 2000-2015

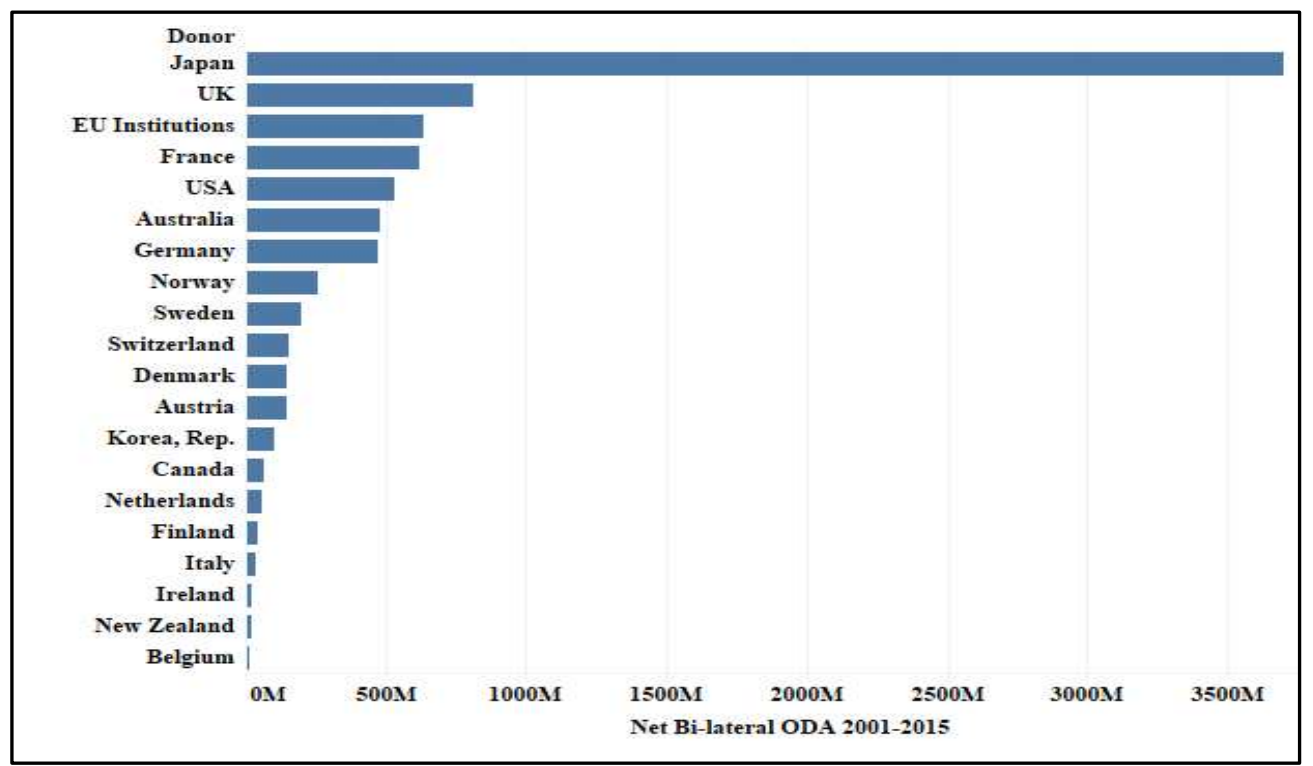

Source: Author's compilation from the World Development Index Data.

China and Russia's unreserved support to Myanmar owes to a complex set of geopolitical considerations, security issues, transit rights, access to natural resources, energy and military sales ${ }^{61}$ - detail examination of which is beyond the scope of this paper. However, figure 4 shows Myanmar's weapon purchase between 2001-2016. ${ }^{62}$ Evidently, the western arms embargo was pivoted mainly by the supply from Russia and China. Justifying the recent sale of six Sukhoi jets to Myanmar, the Russian Deputy Defence Minister remarked that these jets are 'crucial for protecting the country's [Myanmar's] territorial integrity and countering terrorist threats. ${ }^{63}$ Such reasoning shows how the crisis is used as an opportunity. The sharp increase of weapon sale after 2010 tends to suggest that the lifting of the western sanctions served as an incentive for China and Russia to beef up their supply to Myanmar.

\footnotetext{
${ }^{61}$ See David I. Steinberg, and Fan Hongwei (2012), Modern China-Myanmar Relations: Dilemmas of Mutual Dependence, Nordic Institute of Asian Studies, Copenhagen, Denmark, pp.306-342.

${ }^{62}$ SIPRI's Trend Indicator Value (TIV) accounts 'known unit production costs of a core set of weapons' rather than the price paid. See SIPRI Arms Transfers Database - Methodology, https://www.sipri.org/databases/armstransfers/background/ (accessed 27 December 2017).

${ }^{63}$ Emphasis added. See 'Russia ignores US charges over Sukhoi fighter jet supplies to Myanmar Kremlin', Tass, 26 January 26, 2018, http://tass.com/defense/987050, (Accessed 9 February 2018).
} 
Pathways to Justice for 'Atrocity Crime' in Myanmar - is there Political Will?

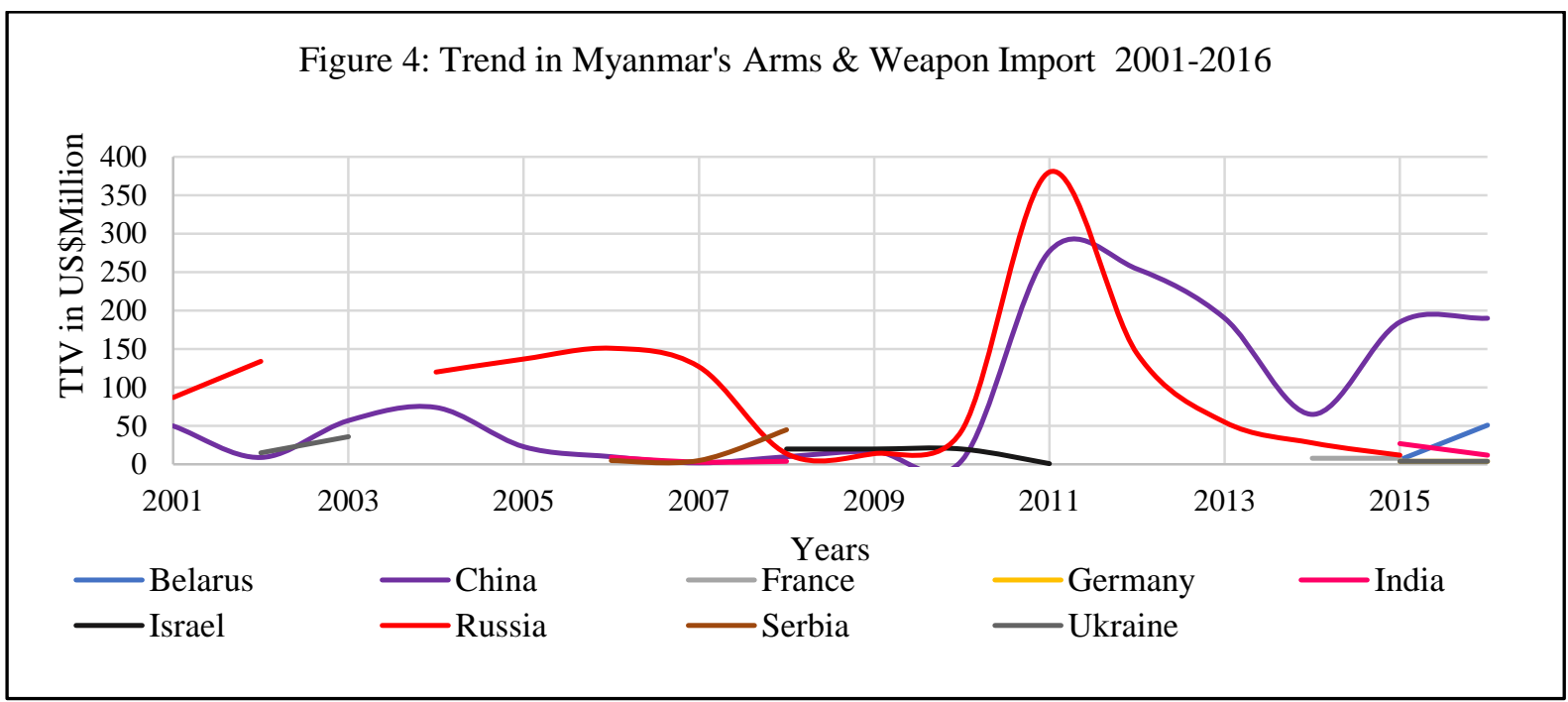

Source: Author's compilation from SIPRI Arms Transfers Database

In sum, the current state of material incentives/disincentives looks insufficient to change the status quo. The collective political will of the key external actors are fractured and inadequate to effect change pursuing justice for the atrocity crimes. Such a condition begs to notch up the material disincentives such as targeted sanctions and global arms embargo. Such action may have a secondary effect encouraging/restricting Russia and China to limit their supply of arms to Myanmar military. Similarly, the bilateral aid to Myanmar needs to be, at least, conditional and/or staggered to facilitate achieving specific actions towards justice.

Analysing the material factors do not tell the whole story of an actor's political will. Political will is also about 'motives, thinking, and feelings' of the actor and other political actors pursuing or opposing the same aims. ${ }^{64}$ It is difficult to proxy such intangible aspects. However, some evidence can be drawn from China and Russia's 'thinking and feelings' from their past actions in the UNSC to establish two ICTs under Chapter VII of the UN Charter. Russia voted in favour of establishing the ICTY and ICTR (pathway 2). As the President of the ICTY committee, Russia co-sponsored the draft Resolution stating 'the entire international

${ }^{64}$ See Understanding 'Political Will', p.3. 
Pathways to Justice for 'Atrocity Crime' in Myanmar - is there Political Will?

community ..., through the Tribunal, will be passing sentence on those who are grossly violating not only the norms of international law but even quite simply our human concepts of morality and humanity (italic added). ${ }^{65}$ China provided qualified support to establish ICTY ${ }^{66}$ and abstained from voting during the ICTR ${ }^{67}$ China regarded that perpetrators of such crimes 'should be brought to justice' and called the UN to adopt a 'prudent attitude' by signing a treaty with the host country to provide 'solid legal foundation' of the Court ${ }^{68}$ Apart from providing funding, Russian and Chinese judges have also served in the ICTs.

China's one belt one road (OBOR) project that runs through the Rakhine state has also been referred as the critical geopolitical reason for its unreserved support to Myanmar. ${ }^{69}$ However, pushing the allegation of atrocity crimes under the rug, committed in its neighbourhood risks not only tainting China's OBOR project - an unnecessary price for a benevolent and unique initiative, but also dampening China's growing clout of 'soft power.' The three-stage approach suggested by China hints at a regional solution to resolve the crisis to salvage a global backlash. ${ }^{70}$ The proposal includes: (i) effecting a ceasefire on the ground, (ii) safe repatriation of the refugees and (iii) a plan for the economic development of Rakhine. However, current Chinese program does not include investigating the allegation and/or prosecuting the perpetrators and stands at odds with its past moral position in the UNSC.

\footnotetext{
65 See $S / P V$ 3217, 25 May 1993, pp.44-45.

${ }^{66}$ The Chinese envoy to the ICTY meeting stated that 'This political position of ours, however, should not be construed as our endorsement of the legal approach involved' adding that the ICTY can only be an 'ad hoc arrangement' and shall not 'constitute any precedent'. See Ibid, p.32-33.

${ }^{67}$ See $S / P V .3453,8$ November 1994, p. 11.

${ }^{68} \mathrm{Ibid}, \mathrm{p} .33$.

69 See Parth Sharma, Rohingya Crisis: The Larger Geopolitics Nobody Is Talking About, The Huffington Post, 23 September 2017. The Siasat Daily 'What connects Rohingya genocide with China's 7.3 billion investment in Rakhine state?' Saibal Dasgupta, China's huge Rakhine investment behind its tacit backing of Myanmar on Rohingyas, The Times of India, Sep 26, 2017.

${ }^{70}$ See Yimou Lee, China draws a three-stage path for Myanmar, Bangladesh to resolve Rohingya crisis, The Reuters, 20 November 2017.
} 
Pathways to Justice for 'Atrocity Crime' in Myanmar - is there Political Will?

Be that as it may, the overall evidence tends to suggest that Russia and China are not

fundamentally opposed to the idea of pursuing justice. Russia has been party to both pathway 1 and 2. In contrast, China seems to prefer a consensus pathway (pathway 1 and 3). Given China's strong preference for host country's endorsement to establish ICTs, it is plausible to assume that China will prefer pathway 3, reached through a bi-lateral/regional consultation.

The Rohingya crisis is also labelled as an 'ASEAN challenge' calling the regional body for effective action ${ }^{71}$ in light of its Charter $^{72}$ and the Huma Rights Declarations. ${ }^{73}$ Three ASEAN countries (Thailand, Malaysia, and Indonesia) houses significant Rohingya refugees. Despite compelling reasons, ASEAN's 'political will' to address the issue, let alone pursuing justice is missing. Several channels like the ASEAN Intergovernmental Commission on Human Rights (AICHR), ASEAN Sectoral Ministerial Bodies ${ }^{74}$ and the office of the ASEAN Secretary and the Troika ${ }^{75}$ have remained silent. ${ }^{76}$ Popular support and sympathy towards the Rohingyas in ASEAN cities ${ }^{77}$ contrasts such lack of political will. A strong willingness can also iron out the

${ }^{71}$ See, The Rohingya Crisis and the Risk of Atrocities in Myanmar: An ASEAN Challenge and Call to Action, ASEAN Parliamentarians for Human Rights, April 2015. Pavin Chachavalpongpun, Rohingya refugee crisis shames Southeast Asia, The Japan Times, 21 May 2015. Jera Lego, Why ASEAN Can't Ignore the Rohingya Crisis, The Diplomat, 17 May 2017.

${ }^{72}$, The purpose and principles of the ASEAN Charter emphasise the promotion and protection of human rights and freedom stressing the rights and responsibilities of member states. See, The ASEAN Charter, http://asean.org/, (Accessed 9 February 2018)

${ }^{73}$ The declaration recognises the need for accountability (Article 9) but refers to the ASEAN Charter for the parameters to promote and protect human rights (Article 39). See ASEAN Human Rights Declaration, http://aichr.org/documents/, (Accessed 9 February 2018)

${ }^{74}$ For example, the ASEAN Defence Ministers Meeting (ADMM) and the ASEAN Defence Senior Officials Meeting (ADSOM) provides a platform to engage the Myanmar military.

${ }^{75}$ ASEAN Troika consists of the Foreign Ministers of the present, past and future chairs of its Security Committee. It was set up to address urgent and important regional political and security issues.

${ }^{76}$ The 2017 summit declaration did not mention the Rohingya issue but expressed support for the country's efforts to bring peace and harmony to northern Rakhine. See ASEAN silent on Rohingya crisis, The Daily Star, 17 November 2017. For the evidence of AICHR silence see Gamez, K. Ramos, Examining the AICHR: The Case Study of The Rohingya Crisis, A dissertation submitted in partial fulfilment of the requirements for the degree of LL.M. in International and European Law (International Human Rights Law), Tilburg University, June 2017.

${ }^{77}$ Support are evidenced not only by the rallies and protests but also government actions. Apart from aid agencies, the Indonesian military had also sent relief well for the Rohingyas in Bangladesh. 
Pathways to Justice for 'Atrocity Crime' in Myanmar - is there Political Will?

challenges and empower the AICHR by expanding its mandate to include country visits to inquire and record complaints about serious human rights violations. It can lead to establishing a joint UN-ASEAN project for an independent and impartial investigation of human rights violations in Rakhine. Singapore - the new ASEAN Chair is better poised to persuade Myanmar as it is one of the most significant trading and FDI partners of Myanmar. ${ }^{78}$ It needs to be emphasised that there has always been a general reticence to the human rights discourse and lukewarm response to such issues by the ASEAN states. ${ }^{79}$ The doctrine of 'development ought to precede human rights', and the need for maintaining amicable foreign policy contributed to such ambivalence to deal with human rights violations.

In sum, international 'political will' on this issue is marred by inconsistent actions of the key actors. First, the current state of external incentives/disincentives is neither conducive nor sufficient to persuade Myanmar to pursue justice. Thus, the flow of ODA and FDI, exercise of the sanctions and arms embargoes by the key political actors including Japan and Singapore needs to be fine-tuned and conditioned reflecting their resolve and commitment to ending the culture of impunity for atrocity crimes. Second, to reconcile the geo-strategic concerns, a consensus mandate for the ICTM-R focusing on prosecuting the perpetrators and not the state and keeping provisions to integrate GoM's judicial and institutional capacity may be helpful. Such an approach may encourage China and Russia to stand by their moral principles as maintained during the ICTY and ICTR. The combined efforts could persuade Myanmar and thus follow pathway -1 without invoking Chapter VII by the UNSC. However, in case Myanmar rejects the consensus proposal, pathway -2 remains open invoking Chapter VII and

78 Within the ASEAN, Singapore has the highest FDI to Myanmar reaching from US\$120 million in 2012 to US\$1,541.18 million in 2016. See https://data.aseanstats.org/\#, accessed 12 February 2018. 79 See Hsien-Li Tan, The ASEAN Intergovernmental Commission on Human Rights: Institutionalising Human Rights in Southeast Asia, Cambridge University Press, pp.25-28. 
Pathways to Justice for 'Atrocity Crime' in Myanmar - is there Political Will?

the Court will have to be established in any of neighbouring countries. Indeed, Myanmar's national security advisor $U$ Thaung Tun has recently stated that the UN may invoke the Genocide doctrine to intervene in Rakhine under the R2P principle. ${ }^{80}$

\section{Harnessing Domestic Political Will}

Myanmar's domestic 'political will' needs to be viewed considering the brittle power equilibrium between the military and civilian leadership propped by the deep-rooted hatred against the Rohingyas. Such condition has constrained the political leadership and blinded their moral judgements pushing to take a utilitarian approach hindering justice. The limited civilian space and the rising influence of the Buddhist nationalist make it a 'political suicide' for anyone siding with the Rohingyas, let alone seeking justice. ${ }^{81}$ Thus, the domestic willingness has so far remained deflationary and resulted in replacing the commander of Western Command and acquitting the security forces of any wrongdoing through an internal investigation. ${ }^{82}$ The civilian leadership has apparently allied with the military, losing their hard-earned support and legitimacy from the international community through prolonged struggle. ${ }^{83}$

It is demanding but not impossible to conceive a change of the domestic political will. Apart from fine-tuning the external incentives/disincentives as discussed above, it would require, a renewed advocacy and sensitisation. The activities of several CSOs in Myanmar (see Annex

\footnotetext{
80 The Security Advisor's remarks came after Myanmar was listed as 'red colour country' by the UN. See Lawi Weng, 'Govt Frets UN Will Invoke Genocide Doctrine to Intervene in Rakhine' The Irrawaddy, 27 November 2017.

${ }^{81}$ See Aye Thein, Putting Myanmar's 'Buddhist Extremism' in an International Context, The Irrawaddy, 3 September 2017.

${ }^{82}$ The investigation was led by Inspector-General of Defence Services, Lt-Gen Aye Win. See 'Myanmar Army Denies Abuses against Rohingya after Investigation,' The Irrawaddy, 14 November 2017.

${ }^{83}$ See, 'Rohingya Refugee Crisis: It's Not Muslims vs Buddhists, Says Writer Bertil Lintner' The Irrawaddy, 11 December 2017.
} 
Pathways to Justice for 'Atrocity Crime' in Myanmar - is there Political Will?

B) testifies that such 'agency' to initiate change exist. ${ }^{84}$ As the legitimate representative of the

Union, the civilian leadership needs to recognise the gravity of the issue and declare an end to impunity for such crimes. The elected leadership needs to expand the civilian space embracing the fact that providing impunity for atrocity crimes is not compatibility with democratic value, peace and reconciliation. Just as the new political leadership has introduced the idea of 'democratic federal union', challenging the old 'unitary idea' of statehood to consolidate democracy and reconciliation, ${ }^{85}$ they need to stand up for ending impunity to place Myanmar alongside the global democratic polity earned through so many struggles and sacrifices. Dispensing political expediency, such bold step by the civilian leadership can instil respect for human rights, sympathy for the victims and consolidate peace and democracy, contributing to the pursuit of justice. Conversely, any delays/absence of taking such bold steps can shrink the civilian space further.

Second, the military leadership needs to view national security in terms of protecting and benefitting the people and not the military alone. The prolonged military rule has created an uneven society in Myanmar as evidenced by the data of Global Militarisation Index (GMI) plotted in figure 5. The GMI projects a relative account of country's military expenditure, personnel and heavy weapons purchase with societal factors like health spending, number of

\footnotetext{
${ }^{84}$ For example, over 100 CSOs in Myanmar signed a letter in opposition to the "Protection of Race and Religion Bills," advanced by the influential ultra-nationalist group Ma-Ba Tha engaged to inflame antiMuslim prejudice and fear (ASEAN Parliamentarians for Human Rights, p.5). CSOs like the Global Justice Center (GJC) and the Gender Equality Network (GEN) have also spoken out to eliminate impunity calling for the trial of military personnel accused of such crimes (Shadow Report on Myanmar for the 64th Session of the CEDAW Committee July 2016, p.24).

${ }^{85}$ The idea of a federal union was considered a taboo under the military. The new Nationwide Ceasefire Agreement (NCA), initiated in 2011, is based on the idea of a 'democratic federal union'. The new government agreed it during the formulation of the NCA. See Thein TT. Burmese govt agrees, in principle, to a federal union. DVB, 16 August 2014, https://www.dvb.no/news/burmesegovt-agrees-inprinciple-to-a-federal-union-burma-myanmar/43310/, accessed 12 November 2017.
} 
Pathways to Justice for 'Atrocity Crime' in Myanmar - is there Political Will?

to physicians, and population. The overall militarisation score thus reflects the relative weight and importance of the military apparatus of the state in relation to its society. ${ }^{86}$

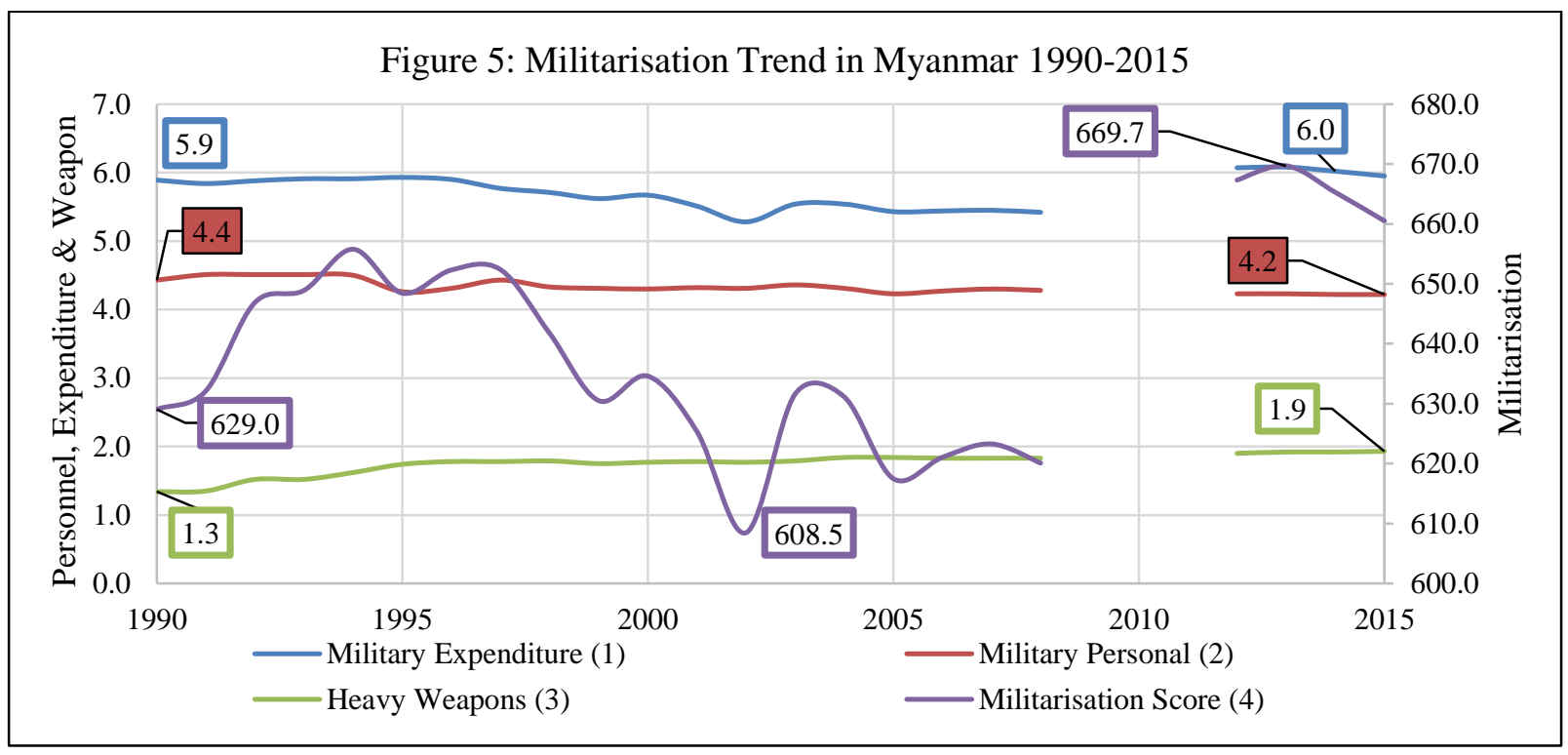

Source: Author's compilation from GMI data.

The trend suggests that the military was mostly unscathed by the sanctions. The trend in militarisation started to decline sharply after 2000 coinciding with harsher western penalties, only to reach new heights in 2010 which coincides with the lifting/easing up of the sanctions. Increased external assistance after 2010 allowed to free up more assets, resulting from an increased militarisation and at a much higher speed. ${ }^{87}$

${ }^{86}$ The total militarisation score (4) is based on three dimensions: (1) military expenditure and (2) personnel dimension, based on a weighted scale of 0 (lowest) - 8 (highest) and the (3) heavy weapons index, based on a 0 (lowest) to 4 (highest) scale. See Mutschler, Max., M., Global Militarization Index, 2016, BICC, Bon, Germany, https://gmi.bicc.de/ (Accessed 10 February 2018).

${ }^{87}$ For example, GoM's health spending after 2010 had a little increase, reaching 3.59 percent in 2014 , while the military expenditure jumped from 9-12 percent to 15-18 percent in 2015. See Yu M., Win Khine L., Shiao, L. Wen-Shuan, Thandar, Moe M., Amiya, Rachel M., Shibanuma, A., Tun, Soe Saw,, and Jimba, Masamine (2013) Taking stock of Myanmar's progress toward the health-related Millennium Development Goals: current roadblocks, paths ahead, International Journal for Equity in Health, http://www.equityhealthj.com/content/12/1/78/, accessed 28 November 2017.World Development Indicators, https://datacatalog.worldbank.org/dataset/world-development-indicators/ (accessed 12 November 2017] 
Pathways to Justice for 'Atrocity Crime' in Myanmar - is there Political Will?

This evidence shows that Myanmar's transition to democracy came at a price, in which the

military continues to benefit the most. Thus, country's civilian polity needs to reclaim their position, demand distributive justice of the internal and extern resources that are meant for improving their lives. A renewed reflection of the key actors about the nature and conditions of material assistance to Myanmar and their utilisation can shape the domestic political will. Such reflection will help the military to realise adopting people-centric national security abandoning the culture of impunity as it risks tainting the total forces. This may encourage the military to single out the units and individuals who committed or conspired to the atrocity crime and make them accountable to remove the stigma attached to the Myanmar military.

Apart from legislative approval (as in Cambodia), peace treaty (as in Sierra Leone) is also a legitimate anchor for domestic 'political will' ${ }^{88}$ In Myanmar context, domestic instruments and institutions such as the Nationwide Ceasefire Agreement (NCA) and National Reconciliation and Peace Centre (NRPC) ${ }^{89}$ could be useful to pursue justice. Despite a conditional and exclusionary practice, ${ }^{90}$ the NCA provides a starting framework as it guarantees the political dialogue (Chapter 5) and suggests confidence-building measures such as health, education, and socio-economic service delivery provisions under "interim

\footnotetext{
${ }^{88}$ See the Summary Report, 7th colloquium of international Prosecutor, Local Prosecution of International Crime 4-5 November 2014, Arusha, Tanzania, [Online] http://unictr.unmict.org/sites/unictr.org/files/legal-library/141104-7-colloquim-of-internationalprosecutors-en.pdf/ (Accessed 25 December 2017)

${ }^{89}$ The NCA is the first negotiate multilateral ceasefire agreement formalised on 31 March 2015, outlining a 7-step roadmap for peace and national reconciliation. The NRPC is the successor of Myanmar Peace Centre (MPC) formed vide Presidential Order 50/2016. It is under the Office of State Counsellor and mandated for national reconciliation \& peace processes, coordination with ethnic groups, civil society, international donors, and experts. See National Reconciliation \& Peace Centre, Summary, http://www.mmpeacemonitor.org/stakeholders/myanmar-peace-center/227-nrpc, (accessed 8 November 2017).

90 The excluded Ethnic Armed Groups in the NCA includes bigger groups like Arakan Army (AA), Myanmar National Democracy Alliance Army (MNDAA), Ta'ang National Liberation Army (TNLA), and smaller groups like Arakan National Council (ANC), Lahu Democratic Union (LDU), Wa National Organization / Army (WNO). See The Institute for Security and Development Policy, Myanmar's Nationwide Ceasefire Agreement: Background, October 2015, p. 2. www.isdp.eu, accessed 13 February 2018.
} 
Pathways to Justice for 'Atrocity Crime' in Myanmar - is there Political Will?

arrangements" (Chapter 6) that are conducive to pursue justice. The combined political will of the civilian and military leadership can function through the NRPC facilitating the establishment of either a State Tribunal without any external involvement (pathway 3) or the ICTM-R (pathways 1). Such possibilities satisfy the Chinese view at the UNSC that 'a viable solution will be one that goes hand in hand with the peace and reconciliation process in Myanmar. ${ }^{91}$ However, justice through State Tribunal (pathway-3) may suffer from legitimacy deficit and hinder unrestricted funding from the external sources as evidenced in Cambodian.

\section{Domestic and International Advocacy}

Beyond state agencies, advocacy by the CSOs, institutions, and academia can also harness political will. This was particularly evident in the case of ECCC that has the most chequered history of coming into operation. The Cambodian Genocide Project, Inc. established by the Yale Law School in 1981 and supported by many including the U.S. Institute of Peace, helped to gather documentary evidence and videotaped testimony of many eyewitnesses. ${ }^{92}$ The Campaign to Oppose the Return of the Khmer Rouge (CORKR) was instrumental in its advocacy leading to the adoption of the Cambodian Genocide Justice Act by the U.S. Congress in 1994. The Yale and Harvard Law School have already published legal analysis and reports on the atrocity crimes in Myanmar. ${ }^{93}$ The Permanent Peoples' Tribunal (PPT), held open (people's) trial on the issue. ${ }^{94}$ As discussed before, several other CSOs inside Myanmar are also working on the human rights issue. The 'soft power' of these advocacy groups, including the brave evidence-based reporting by reputed media, can facilitate harnessing the political will.

\footnotetext{
${ }^{91}$ See S/PV.8060, 28 September 2017, p.14

${ }^{92}$ Gregory H. Stanton, Seeking Justice in Cambodia.

${ }^{93}$ Persecution of The Rohingya Muslims: Is Genocide Occurring in Myanmar's Rakhine State? A Legal Analysis, Op Cit., and Crimes in Burma, Op Cit.

${ }^{94}$ See Permanent Peoples' Tribunal, State Crimes Allegedly Committed in Myanmar against the Rohingyas, Kachins and Other Groups, 18-22 September 2017, Kuala Lumpur, Malaysia.
} 
Pathways to Justice for 'Atrocity Crime' in Myanmar - is there Political Will?

A verified and cross-referred initial database on the atrocity crimes prepared by such advocacy groups would be invaluable to influence collective and individual state action through UN or ASEAN under the 'just cause' criteria ${ }^{95}$ and subsequent prosecution. Several UN entities and agencies are mandated for data collection on such crimes. ${ }^{96}$ The UN Office for Genocide Prevention and R2P is mandated for, among others, (i) collection and assessment of information on situations worldwide, (ii) sending fact-finding missions, (iii) dissemination of monthly reports to UN partners (iv) preparation and dissemination to UN partners of analytical briefings on country situations. (v) promote systematic and cohesive information gathering and assessment by the $\mathrm{UN}$ on situations at risk of atrocity crimes. ${ }^{97}$ The division for Advancement of Women of the UN Department of Economic and Social Affairs is authorised to document, disseminate and analyse data on gender-based violence and update their searchable database/ portal. Credible media houses and regional bodies are also acceptable sources. Relentless advocacy by the CSOs, right groups and international organisations bolstered by the media reporting can galvanise support and encourage state actors to take actions.

\section{Concluding remarks}

'Political will' is not a neutral concept. It can produce both benign and invidious outcomes. The atrocity crimes committed against the Rohingyas was not a product of 'limited statehood' but a product of the fractured and invidious nature of the 'political will' of the key domestic and international actors. Such a state of 'political will' privilege immunity over justice. Despite the legislative power criminalising atrocity crimes and important institutional development to

\footnotetext{
${ }^{95}$ For details on threshold criteria for 'just cause', see CISS, The Responsibility to Protect, p. 32-35 96 For example, A /Res61/143, 19 December 2006, mandates relevant UN entities and other regional intergovernmental organisations for 'data collection, processing and dissemination of data, including data disaggregated by sex, age and other relevant information, for their possible use' particularly on all forms of violence against women.

${ }^{97}$ See 'UN Office on Genocide Prevention and the Responsibility to Protect'. Ibid.
} 
Pathways to Justice for 'Atrocity Crime' in Myanmar - is there Political Will?

implement those, the relation of power and privileges between and within the domestic and international actors have triumphed in the context of Myanmar, according immunity to the perpetrators. The ascendancy of the culture of immunity trickles down empowering the perpetrators to hide their criminal responsibilities. Competing accounts of the situation are generated feeding the key actors to justify and strengthen the immunity. However, such a condition is not perpetual. Political will can change. Outlining three potential pathways, this paper suggests how the political will of the global and local actors can be harnessed to pursue justice. It shows that a precisely defined mandate to prosecute the individuals and not the state and provisions to integrate host nation's instruments and capacity could be a viable framework to establish the ICTM-R. It shows that harnessing the 'political will' to pursue justice entail fine-tuning the material incentives/disincentives to Myanmar reflecting the resolve and commitment of the UNSC and key actors like Japan and Singapore to end the culture of impunity. Within Myanmar, the civilian leadership needs to reclaim and expand the civilian space while the military needs to view national security in holistic terms and not just their interests as it risks tainting the total forces for committing atrocity crimes. Finally, the advocacy by right groups and institutions remains an essential catalyst to the entire process of harnessing the political will to pursue justice in Myanmar.

\section{Annex A: International Instruments on Human Rights and Atrocity Crimes}

Annex B: Summary of the CSOs Shadow Report on Human Rights Situation in Myanmar to the UN CEDAW Committee, 2015-2016

Annex C: Summary of the Key Actions by the Host Country and Other Actors to Establish the Four ICTs. 
Table 1: Summary of Justice Served through the Four ICTs (number of individuals)

\begin{tabular}{|l|c|c|c|c|c|} 
& ICTY & ICTR & SCSL & ECCC & Total \\
\hline Indicted/Charged & 161 & 93 & 13 & 15 & 282 \\
\hline Proceedings concluded & 154 & 85 & 10 & 3 & 252 \\
\hline On going & 7 & 0 & 0 & 3 & 10 \\
\hline Acquitted & 19 & 14 & 0 & - & 33 \\
\hline Transferred to State Jurisdiction & 13 & 5 & - & - & 18 \\
\hline Fugitive/At large & 0 & 8 & 1 & - & 9 \\
\hline Indictment Terminated/ & 37 & 8 & 3 & 3 & 51 \\
\hline Withdrawn/Died or illness & & & & & 6 \\
\hline Suspects yet to be Charged & 0 & 0 & 0 & 6 & 6 \\
\hline Soure: Aur
\end{tabular}

Source: Author's compilation from ICTY, ICTR, SCSL, and ECCC official websites. 
Table 2: Relevant International Instruments Ratified/Accessed by Myanmar International Instruments on Human Rights and Date Ratified/ Atrocity Crime Ratified/Accessed by Myanmar

1948 Convention on the Prevention and Punishment of the Crime of Genocide 1976 International Covenant on Economic, Social and Cultural Rights

1981 Convention on the Elimination of All Forms of Discrimination against Women (CEADW) 1990 Convention on the Rights of the Child Accessed Accession 14 Mar 1956

Declaration on

Signed in 2015 but not ratified.

Accession in 1997 Declaration on Article 29

2008 Convention on the Rights of Persons with Disabilities Accession in 1991 Withdrew declaration in 1993

2002 Optional Protocol to the Convention on the Rights of the Child on the involvement of children in armed conflict

2002 Optional Protocol to the Convention on the Rights of the Child on the sale of children, child prostitution and child pornography

Accession in 2011

Signed in 2015 but not ratified.

Source: Author's compilation from UN Treaty Collection 
Table 3: Declarations/Reservation by Signatory States on 1948 Genocide Convention

\begin{tabular}{|c|l|l|}
\hline $\begin{array}{c}\text { Article } \\
\text { VI }\end{array}$ & $\begin{array}{l}\text { 'Persons charged with genocide... shall be tried by a competent } \\
\text { tribunal of the State..., or by such international penal tribunal } \\
\text { as may have jurisdiction with respect to those Contracting } \\
\text { Parties which shall have accepted its jurisdiction.' }\end{array}$ & $\begin{array}{l}\text { Algeria, Morocco, Myanmar, } \\
\text { Philippines, USA, Venezuela }\end{array}$ \\
\hline $\begin{array}{c}\text { Article } \\
\text { VII }\end{array}$ & $\begin{array}{l}\text { Genocide and the other acts enumerated in article III shall not } \\
\text { be considered as political crimes for the purpose of } \\
\text { extradition. The Contracting Parties pledge themselves in such } \\
\text { cases to grant extradition in accordance with their laws and } \\
\text { treaties in force. }\end{array}$ & $\begin{array}{l}\text { Malaysia, } \\
\text { Venezuela }\end{array}$ \\
\hline Article \\
VIII
\end{tabular} $\begin{aligned} & \text { Contracting party can call upon the 'competent organs of the } \\
& \begin{array}{l}\text { UN to take such action under the Charter of the UN as they } \\
\text { consider appropriate for the prevention and suppression of acts } \\
\text { of genocide or any of the other acts enumerated in article III.' }\end{array}\end{aligned}$

Source: Author's compilation from United Nations Treaty Collection. 
Table 4: Declaration/Reservations by Countries on Article VI of 1948 Genocide Convention Myanmar. Nothing contained in the said Article shall be construed as depriving the Courts and Tribunals of the Union of jurisdiction or as giving foreign Courts and tribunals jurisdiction over any cases of genocide or any of the other acts enumerated in article III committed within the Union territory.

Algeria. International tribunals may, as an exceptional measure, be recognized as having jurisdiction, in cases in which the Algerian Government has given its express approval.

Morocco: May be admitted exceptionally in cases with respect to which the Moroccan Government has given its specific agreement.

Philippines. Nothing contained in said articles shall be construed as depriving Philippine courts of jurisdiction over all cases of genocide committed within Philippine territory save only in those cases where the Philippine Government consents to have the decision of the Philippine courts reviewed by either of the international tribunals referred to in said articles.

USA. Reserves the right to effect its participation in any such [international] tribunal only by a treaty entered into specifically for that purpose with the advice and consent of the Senate.

Venezuela. Any proceedings to which Venezuela may be a party before an international penal tribunal would be invalid without Venezuela's prior express acceptance of the jurisdiction of such international tribunal.

Source: Authors compilation from the UN Treaty Collection. 
Table 5: Comparison of the nature and process of establishing the ICTY, ICTR, SCLS and ECCC.

\section{ICTY

1. Mandate: nature and limits

Prosecute persons responsible for Prosecute individuals for the crime specific crimes committed since committed in the territory of Rwanda January 1991 in the territory of the former Yugoslavia. and neighbouring States, between 1

January 1994 and 31 December 1994.
Prosecute persons who bear greatest responsibilities for the grave violation of international humanitarian law and SL law during the civil war after 30 Nov 1996.

2. Political Will (international): What UN instrument formally initiated the process of establishing the Court?

Acting under Chapter VII, the UNSC Acting under Chapter VII, the UNSC The UNSC unanimously (15-0)

unanimously (15-0) adopted

Resolution 827 (1993).

Unwilling acceptance. All 14

Permanent Judges appointed by the

UNGA and UNSC (Ad-litem). Court

located outside the host country.

\section{adopted (13-1-1) Resolution 955 \\ (1994) China: abstained, Rwanda: \\ against.}

\section{and Involvement in the Court composition and establishment}

\section{Voted against despite requesting to}

set up the Court with temporal jurisdiction from 1 Oct 1990 to $17 \mathrm{Jul}$

1994. All judges appointed by UN.

Court located in Arusha, Tanzania.
Crimes committed between 17 April

1975 to 6 January 1979 by the senior

leaders and those who are most

responsible in Democratic Kampuchea.
Willing. Requested to set up SCSL in light of the Lomé Peace Agreement (Article XXVI). Court located in host country (initially). GoSL appoints $6 / 16$ judges.
Commission on HR Resolution 1997/49, (1997); UNGA Resolution A/RES/ 52/135 (1997) A/ RES/ 53/145, (1999)

Willing. Requested to setup ECCC Passed the ECCC Law \& signed MoU with the UN. Court is in host country who appoints 3/5 Pre-trial \& Trial and 4/7 Supreme Court Chamber judges.

4. Party to Key International Instruments on Atrocity Crime: Ratification/accession (i) 1948 Genocide Convention

\begin{tabular}{|c|c|c|c|}
\hline $\begin{array}{l}\text { Ratified in August } 1950 \text { (Former } \\
\text { Yugoslavia) }\end{array}$ & $\begin{array}{l}\text { Accession in } 1975 \text { (reservations on } \\
\text { Article IX withdrew in 2008). }\end{array}$ & Not a party & Accession in Oct 1950 \\
\hline \multicolumn{4}{|c|}{ (ii) 1949 Geneva Conventions and Protocols } \\
\hline $\begin{array}{l}\text { Bosnia \& Herzegovina (Dec 1992) } \\
\text { Croatia (May 1992) Serbia (Oct 2001) }\end{array}$ & $\begin{array}{l}\text { Convention (May 1964), Protocol I \& } \\
\text { II (Nov 1984) }\end{array}$ & $\begin{array}{l}\text { Convention(June 1965), Protocol I \& II } \\
\text { (Oct 1986) }\end{array}$ & $\begin{array}{l}\text { Convention (Dec 1958), Prot } \\
\text { II (Jan 1998) }\end{array}$ \\
\hline
\end{tabular}

Croatia (May 1992) Serbia (Oct 2001) II (Nov 1984)

(Oct 1986)

II (Jan 1998)

(iii) Acceptance of the Competence of the International Fact-Finding Commission according to article 90 of Additional Protocol I
Bosnia \& Herzegovina (Dec 1992),
Party since July 1997
Not a party
Not a party

Croatia (May1992), Serbia (Mar 2001)

(iv) 1998 Statute of the International Criminal Court

\author{
Bosnia \& Herzegovina (Apr 2002); \\ Not a party \\ Party since Sep 2000 \\ Croatia (May 2002),Serbia (Sep 2001) \\ Source: Author's compilation from the official websites of ICTY, ICTR, SCSL, ECCC and UN Treaty Collection.
}

Party since Apr 2002. 
Table 6: Potential Pathways of Establishing ICM-R

\section{International Political Will}

\begin{tabular}{|c|c|c|}
\hline & \begin{tabular}{|c|} 
Willing / Willing \\
Pathway -1 \\
(ICTM-R formed on the \\
Principles of Complementarity )
\end{tabular} & $\begin{array}{l}\text { Unwilling/ Willing } \\
\text { Pathway -2 } \\
\text { (Chapter VII invoked to form } \\
\text { ICTR-M outside host state) }\end{array}$ \\
\hline Political Will & $\begin{array}{l}\text { Willing/ Unwilling } \\
\text { Pathway -3 } \\
\text { (State Tribunal with contested } \\
\text { legitimacy/recognition) }\end{array}$ & $\begin{array}{c}\text { Unwilling/ Unwilling } \\
\text { Pathway -4 } \\
\text { (Current status quo condition, } \\
\text { Trial Unlikely) }\end{array}$ \\
\hline
\end{tabular}


Figure 1: EU Santions on Myanmar Till 2013

(Number of Entities and Individuals)

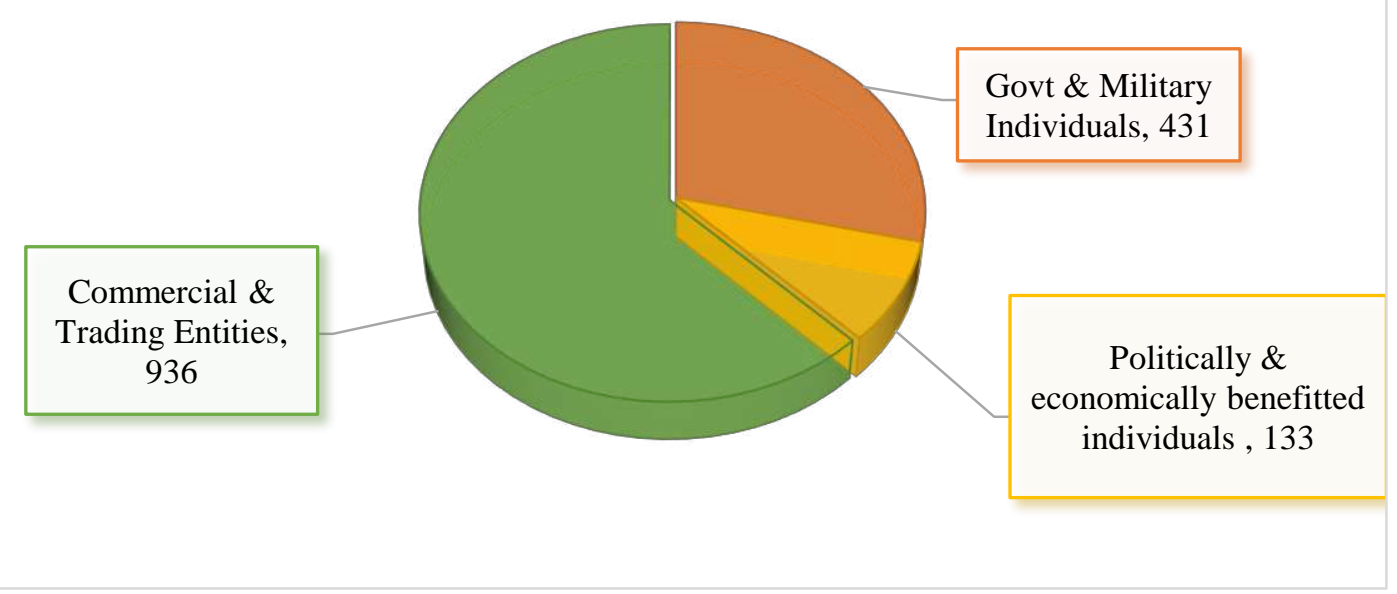

Source: Author's compilation from Annex I - V of Council Decision 2010/232/cfsp 26 April 2010. 
Figure 8: Flow of FDI and ODA to Myanmar and Cambodia 2000-2015

(BoP, Current US\$)

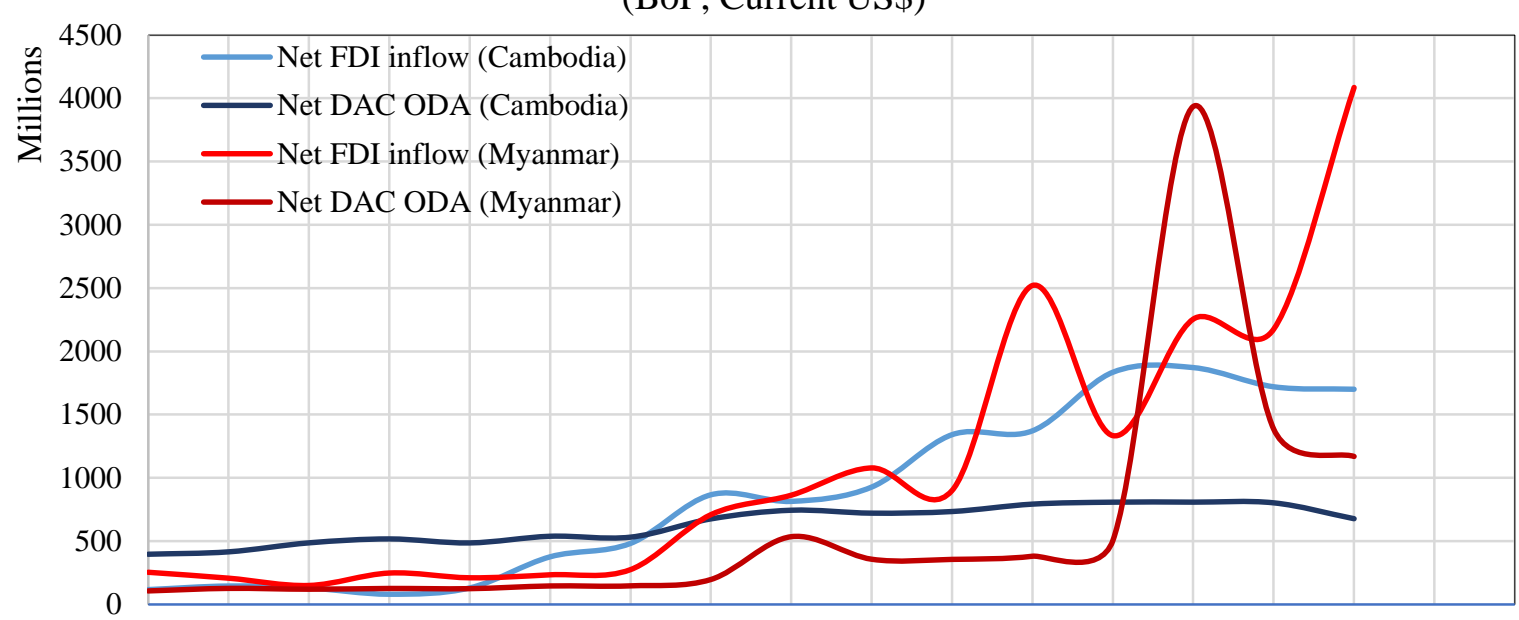

200020012002200320042005200620072008200920102011201220132014201520162017

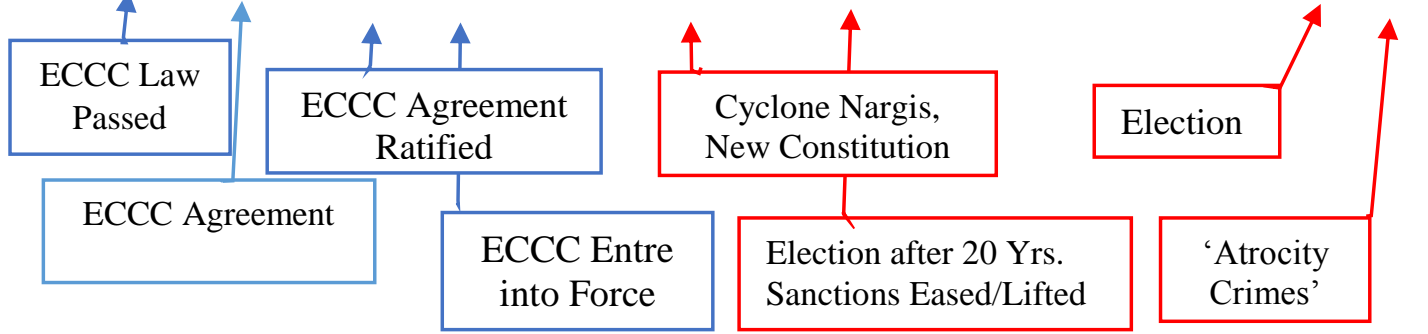

Source: Author's compilation from World Development Index data. 
Figure 3: Top 20 Donors of ODA to Myanmar 2000-2015

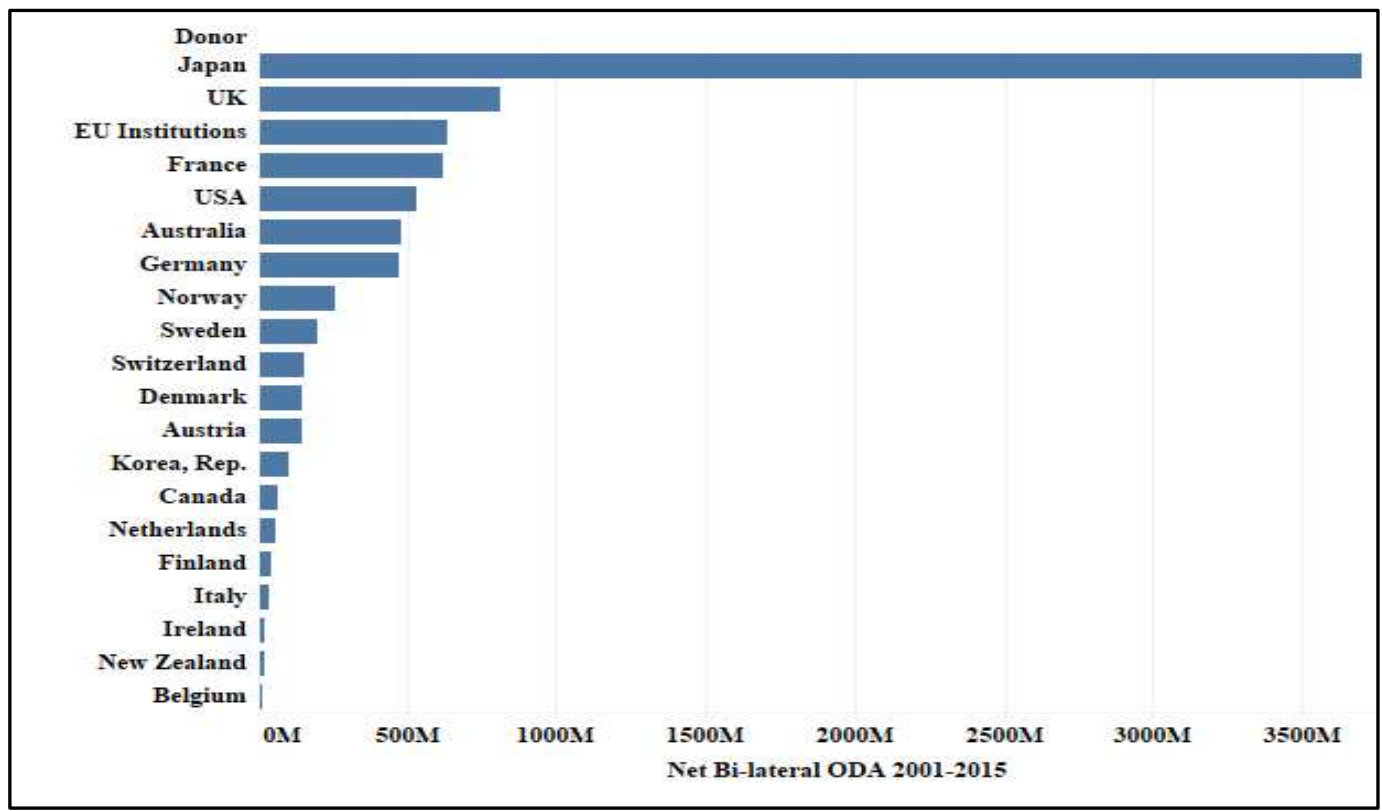

Source: Author's compilation from World Development Index Data. 
Figure 4: Trend in Myanmar's Arms \& Weapon Import 2001-2016

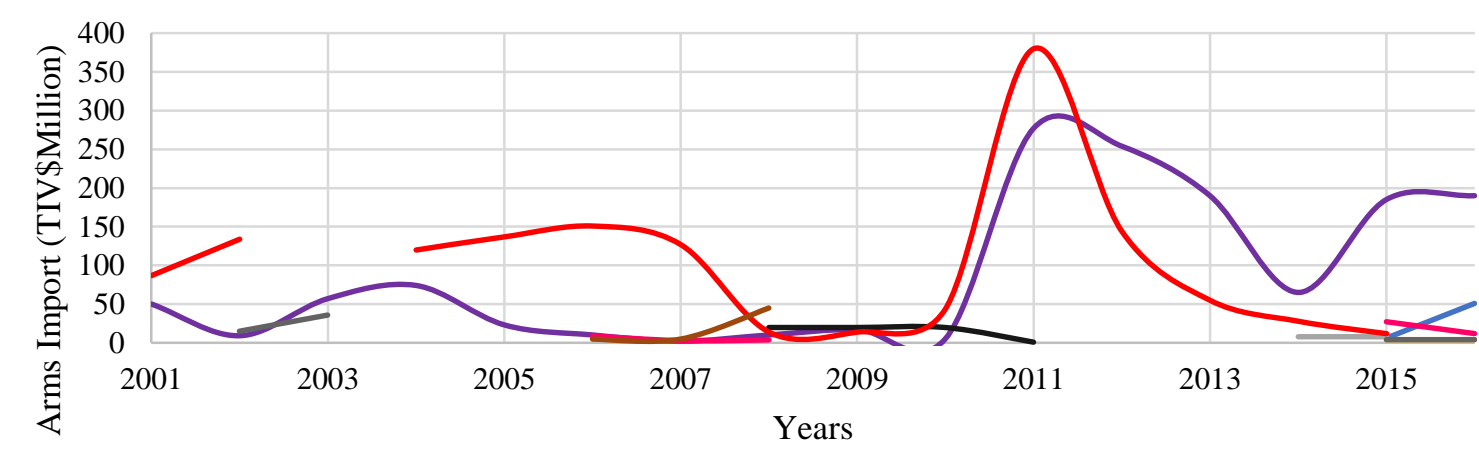

$\longrightarrow$ Belarus —China — France — Germany — India — Israel — Russia — Serbia — Ukraine

Source: Author's compilation from SIPRI Arms Transfers Database 


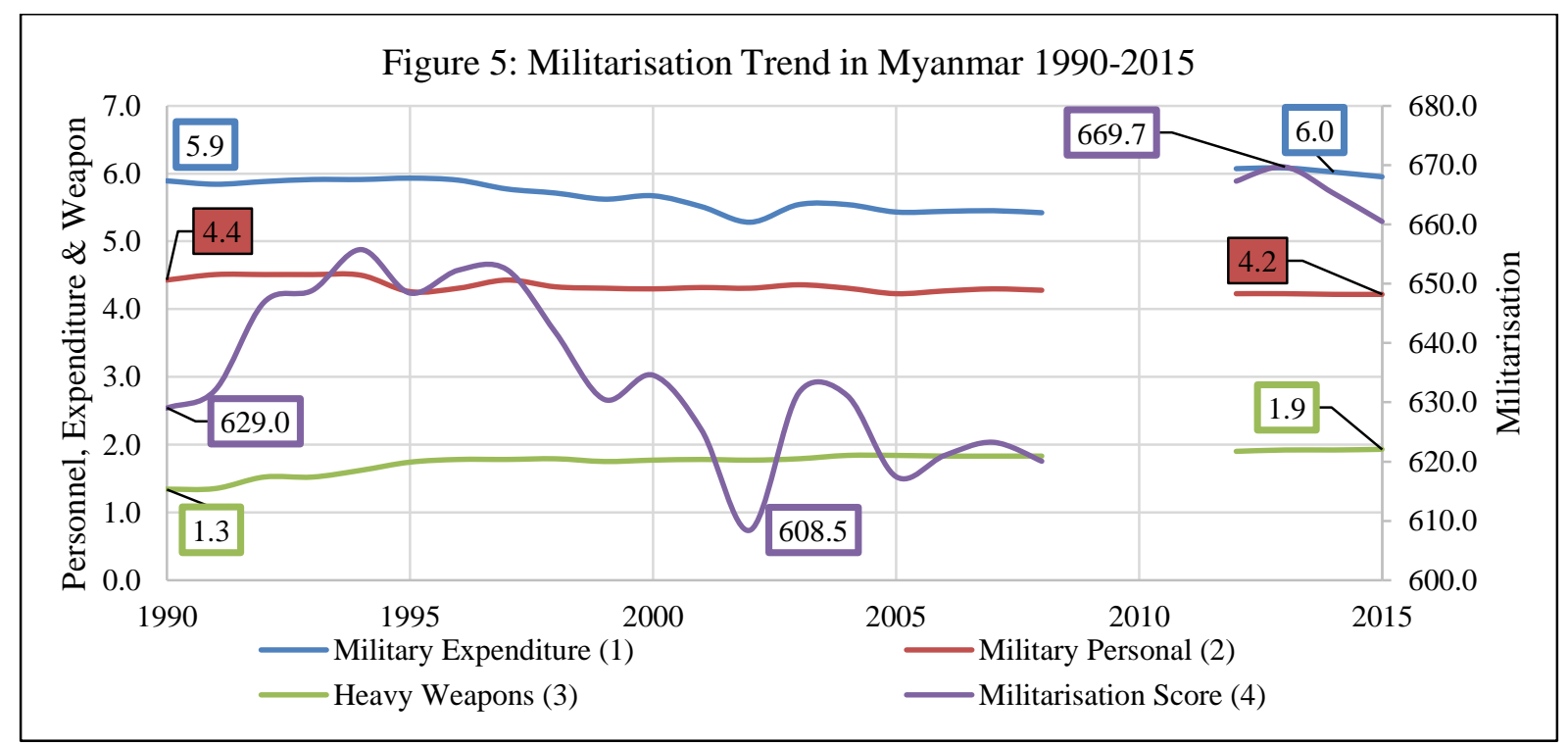

Source: Author's compilation from GMI data. 


\section{Annex A: International Instruments on Human Rights and Atrocity Crime}

List of United Nations Human Rights Conventions and protocols

1. Convention on the Prevention and Punishment of the Crime of Genocide. Paris, 9 December 1948

2. Convention on the Elimination of All Forms of Racial Discrimination. New York, 7 March 1966

2a. Amendment to article 8 of the International Convention on the Elimination of All Forms of Racial Discrimination.

New York, 15 January 1992

3. Covenant on Economic, Social and Cultural Rights. New York, 16 December 1966

3a. Optional Protocol to the Covenant on Economic, Social and Cultural Rights. New York, 10 Dec 2008

4. Covenant on Civil and Political Rights. New York, 16 December 1966

4a. Optional Protocol to the Covenant on Civil and Political Rights. New York, 16 December 1966

4b. Second Optional Protocol to the Covenant on Civil and Political Rights, (death penalty). New York, 15 Dec 1989

5. Convention on the non-applicability of statutory limitations to war crimes and crimes against humanity. New York,

26 November 1968

6. Convention on the Suppression and Punishment of the Crime of Apartheid. New York, 30 November 1973

7. Convention on the Elimination of All Forms of Discrimination against Women. New York, 18 December 1979

7a. Amendment to article 20, paragraph 1 of the Convention on the Elimination of All Forms of Discrimination agains

Women. New York, 22 December 1995

7b. Optional Protocol to the Convention on the Elimination of All Forms of Discrimination against Women. New York, Not a party

6 October 1999

8. Convention against Torture and Other Cruel, Inhuman or Degrading Treatment or Punishment. New York, 10

December 1984

8a. Amendments to articles 17 (7) and 18 (5) of the Convention against Torture and Other Cruel, Inhuman or

Degrading Treatment or Punishment. New York, 8 September 1992

8b. Optional Protocol to the Convention against Torture and Other Cruel, Inhuman or Degrading Treatment or

Punishment. New York, 18 December 2002

9. Convention against Apartheid in Sports. New York, 10 December 1985

10. Convention on the Rights of the Child. New York, 20 November 1989

10a. Amendment to article 43 (2) of the Convention on the Rights of the Child. New York, 12 December 1995
Status of Myanmar

Party since 1949 with reservation on Article VI \& VIII

Not a party

Not a party

Party since 2015

Not a party

Not a party

Not a party

Not a party

Not a party

Not a party

Party since 1997 with

reservations on Article 29

Not a party

Not a party

Not a party

Not a party

Not a party

Party since 1991. Withdrew reservations on Article $15 \& 37$

Party since Jun 2000 
10b. Optional Protocol to the Convention on Rights of Child (involvement of children in armed conflict). New York, 25 May 2000

10c. Optional Protocol to the Convention on Rights of Child (sale, prostitution and pornography). New York, 25 May 2000

10d. Optional Protocol to the Convention on Rights of Child (communications procedure). New York, 19 Dec 2011

11. Convention on the Protection of the Rights of All Migrant Workers and their Families. New York, 18 Dec 1990

12. Convention on the Rights of Persons with Disabilities. New York, 13 December 2006

12a. Optional Protocol to the Convention on the Rights of Persons with Disabilities. New York, 13 December 2006

13. Convention for the Protection of All Persons from Enforced Disappearance. New York, 20 December 2006

14. Geneva Conventions, 1949

14a. Additional Protocol (I) to the Geneva Conventions, 1977

14b. Additional Protocol (II) to the Geneva Conventions, 1977

14c. Convention on the Rights of the Child, 1989

14d. Optional Protocol on the involvement of children in armed conflict, 2000

Source: Author's compilation.
Party since 2015

Party since 16 Jan 2012

Not a party

Not a party

Not a party

Not a party

Not a party

Party since 25.08.1992

Not a party

Not a party

Party since 15.07.1991

Party since 28.09.2015 


\section{$\mathrm{CSO}$}

Amnesty

International

CEDAW Action

Myanmar (CAM)

Christian

Solidarity

Worldwide

(CSW)

Global Justice

Center (GJC) and

Gender Equality

Network (GEN)

The Arakan

Project

Women Peace

Network -

Arakan (WPNA)

Women's League

of Burma

Myanmar Nat'1

Human Rights

Commission

(MNHRC)

Relevant Observations /Recommendations

Reports Lack of clarity in several draft laws (i.e. Population Control Healthcare Laws, Buddhist Women's Special Marriage Law) and their potential negative impact in a context where the Rohingyas are denied citizenship and many of the rights and protections. Report claims that the draft Buddhist Women's Special Marriage Law, as it stands, could be interpreted "to target specific communities identified on a discriminatory basis, in violation of international human rights law" calls for several measures to safeguards against discrimination, and the proposed practice of coercive reproductive control such as coerced abortion or forced sterilization (p.5-7).

Recommends zero tolerance policy on violence against women and sexual harassment in conflict-affected areas and a transparent trial processes conducted in 'public domain'. The report does not specifically mentions the word Rohingya.

Focuses on Kachin and Shan peoples but express concern about violence against women from religious minorities. Report claims that 'rape is used as a weapon of war' by Myanmar military and recommends the GoM 'to end the culture of impunity' for such crimes. (p.2).

Observes that the Rohingya's are subject to systematic discrimination and their right to self-determination are continually denied. (pp.101105). It recommends that GoM must combat "Burma's culture of victim blaming" and acknowledge "military's historical and ongoing use of sexual violence in conflict', and prohibit such practice through legislation, policies, protocols and a zero tolerance policy. (p. 120). The 2016 GJC and GEN joint report also recommends to eliminate "impunity for the military and Government actors, including immunities provided for in the Constitution and by legislation. It specifically calls for the trial of military personnel accused of such crimes in civilian courts or in military courts under the Prevention (and Protection) of Violence against Women (PoVAW) law. (p.24). The 2015 Report notes that rape incidents increased from June 2012, perpetrated by State actors in northern Rakhine State (p.12). It recommends GoM to combat all acts of incitement to discrimination, hostility or violence against religious and ethnic minorities, in particular against the Rohingya ... and take swift legal action against perpetrators.', (p.14)

Report recommends to provide information on "efforts to investigate, prosecute, or prevent' gender based violence in northern Arakan State committed by the military, police Border Guard and $\mathrm{Ma} \mathrm{Ka} \mathrm{Pa'} \mathrm{(p.5).} \mathrm{The} 2016$ report mentions the act of rape, gang rape and brutal killings of Rohingya women in northern Rakhine State and notes that 'justifications' for such act include punishment for alleged membership of their sons or husbands in insurgent groups or for their failure to fulfil their forced labour duties (p.8).

Report notes that 'women [in Rakhine state] are driven out of the village' (Annex, p.1) and claims that GoM has 'failed to take action to address violence against women' and to develop and implement 'adequate legal, support, or policy measures to eliminate violence against women and punish perpetrators.' (p.14)

Source: Author's compilation.

Outline GoM measures for improving the gender based violence. It observes that Myanmar's reservation on Article 29 upon ratification is a hindrance for the effective protection for women's rights calling the GoM to withdraw the reservation. 
Annex C: Summary of the Key Actions by the Host Country and Other Actors to Establish the Four ICTs.

\begin{tabular}{|c|c|c|c|c|}
\hline ICTs & $\begin{array}{l}\text { Resolution } \\
\text { Prepared by }\end{array}$ & $\begin{array}{l}\text { Reports to the } \\
\text { Committee }\end{array}$ & Documents/Actions by Host State and Other Actors Reflecting Political Will & Outcome \\
\hline ICTY & $\begin{array}{l}\text { France, New } \\
\text { Zealand, } \\
\text { Russia, } \\
\text { Spain, U.K., } \\
\text { and the } \\
\text { U.S.A. }\end{array}$ & $\begin{array}{l}\text { UN Secretary- } \\
\text { General (S/25104 } \\
\text { and Addendum 1) }\end{array}$ & $\begin{array}{l}\text { Host: Yugoslavia challenged the legality claiming that any trial should be under its 'national } \\
\text { laws, which are harmonised with international law and by competent judicial authorities, in } \\
\text { accordance with the principle of territorial jurisdiction' (A/48/170, S/25801, 21 May 1993). } \\
\text { Bosnia \& Herzegovina and Croatia Joined the meeting without the right to vote. } \\
\text { Others: Mexico (S/25417), Canada (S/25504 and S/25594, S/25765), Russia (S/2553, S/25829), } \\
\text { Brazil (S/25540), USA (S/25575, S/25829); Slovenia (S/25652); Netherlands (S/25716), France, } \\
\text { UK, Spain (S/25829) wrote letters to the UN Secretary-General on the issue. }\end{array}$ & $\begin{array}{l}\text { Resolution } 827 \\
\text { (1993) under } \\
\text { Chapter VII }\end{array}$ \\
\hline ICTR & $\begin{array}{l}\text { Argentina, } \\
\text { France, New } \\
\text { Zealand, } \\
\text { Russia, } \\
\text { Spain, U.K., } \\
\text { and US.A. }\end{array}$ & $\begin{array}{l}\text { Secretary-General, } \\
\text { Commission of } \\
\text { Experts } \\
\text { (S/1994/879) \& } \\
\text { Special Rapporteur } \\
\text { (Human Rights) } \\
\text { (S/1994/1157) }\end{array}$ & $\begin{array}{l}\text { Host: Rwanda denied any 'systematic and organised killings', 'mass exodus of people' to } \\
\text { Tanzania and that 'refugees are not returning because of insecurity'. Questioning UNHCR's } \\
\text { motive, it blamed 'irresponsible media' for 'encouraging divisive mentalities among the } \\
\text { Rwandese along 'ethnic' lines'. Requested the UN to reinforce government efforts to establish } \\
\text { international tribunal by committing funds and voted against the Resolutions as a non-permanent } \\
\text { member of the UNSC (S/1994/1115 } 29 \text { September 1994). } \\
\text { Others: Uganda supported the establishment of ICTR but objected to its jurisdiction in Uganda } \\
\text { (S/1994/1230). }\end{array}$ & $\begin{array}{l}\text { Resolution } 955 \\
\text { (1994) under } \\
\text { Chapter VII } \\
\text { (China } \\
\text { Abstained) }\end{array}$ \\
\hline SCSL & $\begin{array}{l}\text { Not } \\
\text { Applicable }\end{array}$ & $\begin{array}{l}\text { GoSL and the } \\
\text { ECOWAS Report }\end{array}$ & $\begin{array}{l}\text { Host: GoSL requests for establishing a 'Special Court' to pursue justice in light of the provisions } \\
\text { of the Lomé Peace Agreement to bring lasting peace to Sierra Leon. } \\
\text { Others. Economic Community of West African States (ECOWAS) supported to establish the } \\
\text { 'Special Court'. UN interpreted the amnesty provisions of the Lomé Peace Agreement does not } \\
\text { include crimes of genocide, crimes against humanity, war crimes and other serious violations of } \\
\text { international humanitarian law and passed Resolution to establish the SCSL. }\end{array}$ & $\begin{array}{l}\text { Resolution } \\
1315(2000) . \\
1470(2003)\end{array}$ \\
\hline ECCC & $\begin{array}{l}\text { Not } \\
\text { Applicable }\end{array}$ & $\begin{array}{l}\text { Discussed under } \\
\text { UNGA Resolutions } \\
\text { on the 'Situation of } \\
\text { human rights in } \\
\text { Cambodia' }\end{array}$ & $\begin{array}{l}\text { Host: In August 1979, The People's Revolutionary Tribunal tried the Khmer Rouge perpetrators } \\
\text { in absentia and found them guilty. However, the Tribunal is said to have failed meeting } \\
\text { international fair trial standards. Cambodia requested UN assistance, insisting local ownership } \\
\text { for the trials to facilitate national reconciliation, strengthening democracy and individual } \\
\text { accountability. In } 2001 \text {, the Parliament passed the ECCC Law, signed an agreement with the UN } \\
\text { in } 2003 \text { and ratified the UN-Cambodia ECCC Agreement that entered into force in } 2005 \text {. } \\
\text { Others: Apart from the UN and EU, } 29 \text { countries, two individuals (David Scheffer, William } \\
\text { Schabas), three business entities (Foundation Open Society Institute, Microsoft, Information } \\
\text { Today Inc) donated funds for the ECCC. Japan remains the highest ( } 30 \text { percent) donor. }\end{array}$ & $\begin{array}{l}\text { Para } 16 \text { of } \\
\text { Resolution } \\
\text { A/RES/52/135 } \\
\text { accepts \& Para } \\
17, \\
\text { A/RES/53/145 } \\
\text { appoints a group } \\
\text { of experts. }\end{array}$ \\
\hline
\end{tabular}

Source: Author's compilation from relevant UN documents and letters. 